NBER WORKING PAPER SERIES

INTERNATIONAL COMPETITION IN SERVICES

Rachel McCulloch

Working Paper No. 2235
NATIONAL BUREAU OF ECONOMIC RESEARCH 1050 Massachusetts Avenue Cambridge, MA 02138
May 1987

Prepared for Martin Feldstein, ed., The United States in the World Economy, to be published by the University of Chicago Press. The author is indebted to Robert E. Baldwin and J. David Richardson for helpful suggestions, to Robert E. Lipsey and Irving B. Kravis for detailed comments on an earlier version of the paper, and to the Andrew W. Mellon Foundation. The research reported here is part of the NBER's research program in International Studies. Any opinions expressed are those of the author and not those of the National Bureau of Economic Research. 
NBER Working Paper \#2235 May 1987

International Competition in Services

\section{ABSTRACT}

Production of services now dominates economic activity in the United States and most other nations. It is thus natural to find increasing attention on the part of U.S. policymakers to international competition in service activities. Yielding to strong pressure from the United States, members of the General Agreement on Tariffs and Trade (GATT) agreed in September 1986 to include services in the new "Uruguay Round" of multilateral trade negotiations. But there remains widespread skepticism regarding the prospects for these negotiations.

This paper surveys the main issues and evidence relating to U.S. international competition in services. It reviews the forces that have catapulted services to the top of the agenda for the new GATT round; the conceptual issues raised by international competition in services; the growing importance of services in U.S. production and in international transactions; the relationship of services growth to "deindustrialization" of the U.S. economy; the nature and motivation of barriers to international competition in services and their relationship to nontariff distortions of merchandise trade; and the choices awaiting U.S. officials in forthcoming bilateral and multilateral negotiations.

Rachel McCulloch Department of Economics University of Wisconsin Madison, WI 53706

(608) 262-9891 


\title{
INTERNATIONAL COMPETITION IN SERVICES
}

\author{
Rachel McCulloch \\ University of Wisconsin-Madison and NBER
}

\section{Introduction}

Production of services now dominates economic activity in the United States. Whether hailed as the dawn of a new "information economy" or deplored as the key symptom of American industrial decline, the trend in employment is itself beyond dispute. By the 1980s, only one U.S. worker in four was employed in the sectors of the economy producing tangible outputs -manufacturing plus mining, construction, and agriculture. But the increasing role of service-sector employment is by no means unique to the United states. Similar trends have been reshaping the economies of the other industrialized nations and even many less-developed countries.

Given this dramatic economic transformation at home and abroad, it may seem natural to find increasing attention on the part of U.S. policymakers to international competition in service activities. However, unlike domestic production, trade among nations is still dominated by exchange of tangible goods. Moreover, while the role of international service transactions is already significant and while some sectors show potential for rapid growth, the service transactions prominent in international commerce are quite different from the activities typical of the domestic "service economy." 
In recent decades, national markets for tangible goods have become increasingly integrated, and virtually all U.S. goodsproducing industries have experienced significant growth in both exports and competing imports. However, the rapid domestic expansion of service industries reflects the rising importance of health, education, housing, public administration, and other largely untraded service categories in final demand. The current U.S. interest in international service competition is focused on an entirely different group of industries, especially those supplying information-based business services. These industries are small relative to total domestic service-sector employment. And, although some part of their domestic output is "traded" internationally, i.e, produced by residents of one nation for purchase by those of another, U.S. firms serve international markets primarily via local sales of foreign affiliates rather than exports.

\section{Services on the Policy Agenda}

Long ignored by trade officials as a generic issue, international competition in services has achieved high visibility on the global policy agenda just a few years after the subject was first raised by the United States. At the November 1982 ministerial meeting of the General Agreement on Tariffs and Trade (GATT), the United States Trade Representative called for inclusion of service transactions in forthcoming multilateral 
negotiations.' But the developing countries were strongly opposed, and the Ministers merely recommended that members with an interest in service issues undertake their own national studies, exchange information, and report their results at the 1984 GATT session. ${ }^{2}$

Under continuing pressure from the United States, GATT members agreed in september 1986 to include services in the new "Uruguay Round" of multilateral trade negotiations. Yet there remains widespread skepticism regarding progress on service issues. Abroad, the early and persistent enthusiasm of the United states for negotiations on services has caused U.S. trading partners to assume, perhaps incorrectly, that the United States will emerge as the major beneficiary of any liberalization achieved in this area.

The developing nations, led by Brazil and India, actively resisted inclusion of services on the GATT agenda. This resistance was overcome through a compromise that will keep services on a separate negotiating track from merchandise trade,

1 With a few minor exceptions, the rules of the GATT currently apply only to merchandise trade. Outside the GATT
framework, long-established regimes govern international competition in some specific service activities, such as ocean shipping and air transport. However, cartelization rather than liberalization has been the dominent theme. In a few other cases, such as telecommunications, there are sector-specific bodies dealing primarily with regulatory and technical issues and only incidentally with barriers to trade. Also see Stalson
$(1985,30-36)$.

2 See United States Trade Representative (1983). This is the national study submitted to the GATT by the United States in
December 1983 . 
but the developing nations are nonetheless suspicious of the outcome. While the other industrialized nations did eventually support the U.S. initiative on services, few trade officials abroad appear to view the prospects with any degree of enthusiasm. And even among the U.S. policymakers who pressed so vigorously for GATT negotiations on services, opinion remains divided on the best way to bring conflicting national policies toward services under the discipline of GATT rules.

Analysts in some U.S. government agencies worry that the GATT initiative on services may be premature. An extreme example is a recently issued report of the office of Technology Assessment that openly suggests U.S. officials may have erred, perhaps because their decisions were based on inadequate data. The report's summary section gives this evaluation of the U.S. decision to promote negotiations on services (Office of Technology Assessment 1986, 7):

"Consider, specifically, the decision by the United states prior to the 1982 GATT Ministerial to place a high priority on services in the next round -- a decision taken in the midst of a period of deterioration in the ability of the world trading system to management the impacts on trade in goods of nontariff barriers, bilateralism, and the national industrial policies that have become standard in many parts of the world. Would a better grasp of the prospects for U.S. exports of services have led to a different approach to the new round? Certainly the poor quality and coverage of the data impair the ability of policymakers to 
gauge the importance of services trade -- as a whole, on a sector-by-sector basis, or bilaterally."

\section{Analysis of Competition in Services}

Although there is broad agreement on the poor quality of services data, progress in clarifying the nation's policy goals has been hampered also by lack of analytical guidance. Given the huge theoretical and empirical literature on international competition in goods, surprisingly little attention has been devoted until recently to international competition in services. In most empirical research on international trade, services are simply ignored or are treated as nontradable goods. Theorists, in contrast, often imply or state without elaboration that trade in services is conceptually no different from trade in goods, so that standard analyses in areas such as comparative advantage and gains from trade apply equally to international commerce in services.

Each approach has some economic justification. For the classic textbook example of haircuts and for many other types of services important in domestic production, foreign competition is indeed a negligible influence. Yet some important services, including shipping, transportation, and a variety of financial services, have been actively traded for centuries; for these, the determinants of trade and the gains from trade are fundamentally similar to those for merchandise trade.

But given the evident heterogeneity of the activities 
included in the category, does "services" even constitute a useful analytic classification, or is it merely a convenient label for a statistical residual $?^{3}$ The political and economic issues raised by international competition among producers of tangible goods have in practice proved far from simple to resolve, despite ample theoretical and empirical guidance; consideration of services introduces additional layers of complexity. These reflect the intangible nature of the outputs of many service activities, the locational and temporal constraints linking service providers to consumers, and the extensive role of domestic regulation in service activities. Analysts have only begun to grapple with the implications of these special features. In terms of both measurement and interpretation, analysis of service issues is still in its infancy.

All this raises obvious questions about the new GATT negotiations. Do policymakers have a sufficient knowledge base to shape international rules that will promote global efficiency? And do U.S. trade officials have a sufficient knowledge base to

3 In U.S. statistics for the domestic economy, "services" are usually defined to include all sectors except manufacturing, construction, mining, and agriculture. Balance-of-payments accounting conventionally divides current-account transactions into merchandise trade and "invisibles". The "services" added to merchandise trade to form the broader "goods and services" balance in the U.S. international accounts are income from foreign investments, military transactions, travel and transportation, and "other services." (The remaining category of "invisible" transaction is unilateral transfers.) The U.S. Department of Commerce uses the term "business services" to refer to travel, transportation, and "other services" as recorded in the U.S. international accounts. 
identify and pursue the nation's own economic interests in the area of service competition? If not, what can be gained by putting U.S. influence and prestige on the line to bring services into the GATT framework? Is the services item on the GATT agenda truly a generic issue, or is it fundamentally an attempt to improve the international position of a small set of U.S.-based multinational firms in a few industries?

The purpose of this paper is to survey the main issues and evidence relating to U.S. international competition in services. The next section reviews the forces that have catapulted the services issue to the top of the U.S. agenda for forthcoming GATT negotiations.

Section III addresses the question of what is meant by services and by trade in services, focusing on key ambiguities of definition. The discussion emphasizes similarities and differences within the service sector as conventionally defined and between "services" and tangible "goods."

Sections IV and $V$ interpret evidence on the growing importance of services in U.S. production and in international transactions. This evidence indicates the extent to which internationally traded services are unrepresentative of the

4 In a footnote to a statement by the Committee on Changing International Realities of the National Planning Association endorsing Stalson's generally favorable assessment of the prospects for U.S. negotiations on service issues, John C. Carroll of the Communications Workers of America writes, "... I sometimes feel that it is a disservice to the public interest to use the code words of barriers to trade in services to fight for the foreign interests of a handful of large construction, 
services in domestic production.

The sixth section evaluates the influence of various types

of national policies on international competition in services and compares barriers to services competition with nontariff distortions of merchandise trade.

Section VII analyzes some of the choices facing U.S. officials and evaluates the advantages of alternative negotiating approaches in dealing with services issues.

The final section sums up principal conclusions emerging from the survey and emphasizes the links between international competition in services and other international issues on the policy agenda. 
II. Services in the Policy spotlight

For more than a generation, the majority of U.S. workers have been employed in service-producing sectors; for well over a century, employment in the service-producing sectors has been growing steadily as a share of the U.S. labor force. ${ }^{5}$ Thus, while the U.S. can accurately be described as a "service economy," this is hardly a recent development. Why then has the issue of services, barely mentioned in earlier GATT negotiations, emerged suddenly as a top U.S. priority for the Uruguay Round? The burgeoning interest on the part of policymakers and the U.S. business community reflects several independent developments, each of which has generated some domestic support for marketopening measures in this area.

The first development is increasing concern in the United States about the nation's performance in international markets. Until the end. of the 1960s, the technology gap between the United States and other industrialized nations appeared to provide a permanent advantage over foreign competitors, especially in the high-technology industries. Through massive research and development (R\&D) expenditures, U.S. firms created a steady stream of new products and processes. These innovations allowed American manufacturing to remain internationally competitive even given labor costs far higher than those abroad. But the technology gap narrowed with a speed that few anticipated. Through their global investments, American companies played a

5 See Tables 3-5 below. 
major role in the process.

In 1972, the United States recorded its first postwar

deficit on merchandise trade. While the 1972 trade deficit of $\$ 2$ billion seems insignificant relative to those of recent years, it stimulated questions about the course of the U.S. economy and its future position in world markets. The accompanying employment shift toward services, while not a new development, suggested the possibility that U.S. international comparative advantage was shifting from goods to services.

This impression was strengthened by U.S. balance-of-payments data that revealed a growing surplus in the "services" component of the current account. As U.S. merchandise trade performance deterioriated rapidly in the first half of the 1980 s, services continued to make a significant positive contribution. As recently as 1982 , the U.S. surplus on service transactions was large enough to reverse a sizable deficit on merchandise trade, so that the United States still showed a global surplus in the broader category of "goods and services" trade (see Table 1). From this, some analysts inferred that increased market access abroad for U.S. service industries could further enhance their contribution to overall U.S. current-account performance. ${ }^{6}$

Ironically, the healthy growth in the U.S. surplus on

6 Optimism about the outcome of trade negotiations almost always reflects a belief that the nation's exports will increase more than its imports. Progress toward liberalization thus typically rests on the shaky foundation of mercantilistic goals and inconsistent expectations, rather than an accurate perception of mutual gains to be achieved through expansion of both exports and imports along lines of comparative advantage. 
services was due mainly to increases in net earnings on foreign investments at a time of unusually high interest rates. Since then, interest rates worldwide have fallen dramatically.

Moreover, the U.S. net investment position has reversed, with the United states emerging as the leading borrower in international capital markets. Accordingly, the contribution of investment income to U.S. current account performance is likely to become negative in the near future.

In contrast, as detailed in Table 2 , the types of service exports most likely to rise as a consequence of improved market access abroad constitute a very minor portion of the relevant totals. Thus, even highly favorable conditions can be expected to have only a modest effect on the aggregate international position of the United States, although such conditions would provide substantial benefits to a number of U.S. firms.

While some proponents of GATT negotiations on services have stressed the expansion of service trade as a potential replacement for lost market share in manufactured products, others have emphasized complementarity with merchandise trade. In a variety of service activities that include distribution, training, repair, telecommunications, computer software, construction, and leasing, market access in services enhances market opportunities in related merchandise transactions.' This

7 See, for example, United States International Trade Commission (1982). The Office of Technology Assessment regards prospective direct benefits from expanded service exports as modest but acknowledges the possibility that exports of goods may follow from sales of services such as engineering and 
linkage implies that barriers to international competition in services may in effect constitute an important category of nontariff barrier to international competition in goods, especially manufactured goods.

An additional stimulus for attention to services arises from the national debate on "deindustrialization" of the American economy. At a time when U.S. manufacturing employment shows little promise of growth, expansion of the service industries represents an alternative means to improve the nation's economic prospects. Yet the forecast that newly created service jobs will replace jobs lost in manufacturing is itself controverial.

Optimists focus on a relatively narrow set of knowledgebased service activities, including ones closely linked to hightechnology manufacturing. While some of these sectors have indeed enjoyed rapid growth in recent years, their size relative to the broad aggregate of services is quite small, both in the domestic market and in international transactions. Moreover, further decline in the size of the U.S. manufacturing sector is likely to slow or even reverse the growth of associated service activities as well. And U.S. labor unions, which are concentrated in manufacturing industries, point ominously to the low average earnings in many types of service employment and to the lower average rate of productivity increase in services

construction contracts (OTA 1986, 5). 
relative to that in the goods-producing sectors. ${ }^{8}$

Support for including services in future GATT negotiations has also come from the U.S. public officials charged with forming and implementing the nation's policies toward trade. To many policymakers, services represent a promising area for continuing U.S. efforts to maintain open world markets. Negotiations on services could extend the discipline of GATT rules to a new and important category of transactions and might also help to maintain the forward momentum of the liberalization process at a time when the prospect of further progress on merchandise trade issues appears dim. Anticipated trade and employment gains from increased service exports could help to revitalize flagging political support at home for maintaining open markets. 9

Finally, a major part of the impetus for the recent U.S. emphasis on service issues has come directly from the industries and specific firms with an important economic stake in serving international markets. Large international firms in insurance and other financial-services activities and in business-support services such as accounting, law, telecommunications, and data

a Based on an analysis of recent job creation in the United States, the Industrial Union Department of the AFL-CIO concluded that service occupations "experiencing the largest net growth in the number of jobs demand little skill, are only weakly organized into unions, and usually offer little pay -- ranging from building custodians to fast food workers....prospects for upward mobility out of these lower rung jobs...are slight" (AFL-CIO $1984,11-12)$. However, other researchers view growing servicesector employment in a much more favorable light. For example, see Lawrence (1984) and Urquhart (1984).

' Feketekuty and Krause (1986, 89). 
processing have actively promoted U.S. initiatives in the area of services. In many cases, U.S firms expect their best customers abroad to be the foreign affiliates of major domestic clients. Thus, the global expansion of competition in services is in part a reflection of the earlier globalization of U.S. manufacturing industries.

In pressing their case for increased access to foreign markets, the interested firms and industry associations usually make no distinction between services exported from the United states and those provided locally to customers abroad by foreign affiliates of U.S. companies. Yet the two modes of serving foreign markets need to be separated for purposes of policy formation. Both types of transactions can provide substantial benefits to the U.S. economy. They will, however, generate quite different effects on domestic employment and income distribution.

Moreover, improved access for international sales via foreign subsidiaries is fundamentally not a trade issue at all, but, rather, a matter of national policy abroad toward direct foreign investments by U.S. firms. While consideration of trade in services already represents a significant extension of the GATT mandate beyond its current domain, the inclusion of service activities of foreign affiliates of U.S. firms would entail still a further expansion of GATT jurisdiction. ${ }^{\circ}$ This initiative

10 However, trade-related investment policies have also been ranked high on the agenda for the new GATT round by U.S. trade negotiators, along with a third "new" issue, protection of intellectual property. 
comes at a time when the GATT has been less than notably successful in its traditional work of maintaining open world markets for merchandise trade.

In sum, while a number of firms evidently anticipate substantial benefits from U.S. action on services, the national stake in the issue, whether in absolute terms or relative to other issues confronting members of the GATT, is less clear. Also, at least part of the broader enthusiasm for expanding U.S. market access in services reflects a superficial understanding of the role and importance of services in U.S. domestic production and in the nation's international transactions. Has liberalizing international competition in services been ranked too high on the nation's policy agenda? We return to this question at the end of the paper. 
II . Analytical Issues

Despite continuing discussion of the nation's metamorphosis into a "service economy" and, more recently, of the growing importance of U.S. international competition in services, only meager attention has been paid to precisely what activities are entailed or exactly how these activities enter into international commerce. This section focuses on the fundamental issue of what is meant by services, emphasizing similarities and differences within the industries conventionally grouped together as "services" and between the categories of "services" and tangible "goods."

\section{How Services Differ}

To begin with, which are the industries included within the broad category of services? In terms of domestic employment, government (federal, state, and local) is by far the largest among U.S. service industries, obviously one for which international competition is not a pressing concern. Other major domestic service-producing sectors include transportation and public utilities, wholesale and retail trade, health, and financial and business services. ${ }^{1}$ It is in the last category that the U.S. apparently hopes to make major gains via access to foreign markets. But in terms of international trade, travel and

11 See Table 3. Construction, considered a service activity in the international accounts of the United States, is included in the goods-producing sectors in the tabulation of domestic employment by industry. 
transportation currently account for the lion's share of total U.S. receipts from all "service" transactions (excluding income from direct foreign investment; see Tables 1 and 2 ).

Although a number of scholars have attempted to identify the essential features that separate services from other economic activities, the inherent heterogeneity of the category implies that there will be important exceptions to any allegedly common feature. Heterogeneity may be on the rise, with the increasing importance of services that are "knowledge-based" or "informationbased." These closely related categories include services that provide access to proprietary information (from mailing lists to industrial patents and trade secrets) and the services of individuals with specialized knowledge (from nursing to law). In practice, the two categories overlap; for example, an increasing range of services can be provided directly to the customer by skilled individuals or offered indirectly in the form of proprietary computer software packages.

Fundamentally, service activities may be distinguished either by the nature of their products or by the way in which those products are supplied. ${ }^{12}$ Most service industries produce outputs that are intangible and nonstorable, although the rapidly growing category of information-based services offers important exceptions. For sectors such as telecommunications and computers, services and

12 For more extensive discussion of the distinguishing properties of services as economic activities, see Bhagwati (1984), Deardorff (1985), Gray (1983), Kravis (1983), Sampson and Snape
(1985), and Stern and Hoekman (1986). 
tangible goods are often provided together as part of a single transaction. Another characterizing feature of service products is high value-added relative to gross output. Again, however, there is a major exception, wholesale and retail trade, if the value of goods sold is included as an input.

Looking at the production process, services often require physical proximity of the producer and the consumer, a distinction that is particularly relevant for international competition in these sectors, although new communication technologies are changing the importance of this production constraint. For some knowledgebased services, a salient characteristic is strong economies of scale in production. Scale economies may reflect large fixed costs of physical equipment, as in telecommunications; large fixed costs of research and development, as for patented industrial knowledge; or large fixed costs of acquiring managerial or technical expertise which can then be extended inexpensively to additional customers, as in management consulting. Especially in financial service activities, scale offers the further cost advantage of internal risk diversification.

\section{International Competition in Services}

In general, international trade may be regarded as the indirect exchange of productive inputs embodied in the goods traded, i.e., as a substitute for the direct movement of inputs 
across national boundaries. ${ }^{13}$ Opportunities for and gains from international trade in services thus depend on the extent to which this indirect exchange is feasible. Since services are distinguished from tangible goods in part by greater constraints on the physical location of producer and consumer, it is helpful to classify services with respect to such constraints. There are four possible cases: ${ }^{14}$

(1) No required ${ }^{15}$ movement of providers or demanders. These have been called "separated" services (Sampson and Snape, $1985)$ and "disembodied" or "long-distance" services (Bhagwati, 1985). Such services are fundamentally similar to tangible goods with respect to opportunities for trade and gains from trade.

(2) Required movement of providers (demander-located services). Where physical proximity to the market is essential, international competition necessarily entails movement of capital or labor to the production site, as in construction. However, the production process may also involve some inputs in another location (e.g.,

13 A large part of the theoretical literature on international trade deals with the extent to which indirect exchange of factors via trade can achieve the same efficiency benefits in production and consumption as free international movements of the factors themselves.

14 The following discussion is based on Stern and Hoekman (1986).

15 What is technologically required needs to be distinguished from what is cost-efficient or profitable. This distinction is elaborated in the examples below. 
research and development or management). Deardorff (1985) calls these additional inputs "absent factors."

(3) Required movement of demanders (provider-located services). The obvious example is tourism, but in practice health and education are also important categories. Eree "trade" in such services requires unrestricted international movement of potential demanders.

(4) Required movement of either providers or demanders. In this case, production requires proximity, but the activity is "footloose" and can occur in the importing nation, the exporting nation, or even in a third location.

Another relevant classification of services is with respect to their relationship to merchandise trade. Some internationally provided services are complementary to trade in tangible goods (e.g., transportation, insurance, computer software), some offer alternatives to goods trade (e.g., licensing, computing services), while a third group are unrelated to goods trade (e.g., health and education).

Both classification schemes can be useful in sorting out issues of international competition (and barriers to international competition) in the broad range of activities usually lumped together in the category of services. However, any such taxonomy is necessarily arbitrary, and rapid changes in technology may in any case shift a particular activity from one niche into another. 
U.S. firms may offer their services (and also tangible products) for sale abroad through direct exports or through local domestic transactions of a foreign affiliate. ${ }^{16}$ In standard usage, a U.S. service "export" entails production by U.S. residents of a service purchased by a resident of another nation. It is thus the country of residence of the producer and buyer, rather than the site of production, that distinguishes trade in services. While the same definition applies for tangible goods, most trade in goods is accomplished by the movement of the goods themselves across national boundaries. But except for separated services (case 1 above), trade in services involves the movement of the producer and/or the buyer of the service.

As an alternative to exporting, a U.S. firm may establish a foreign subsidiary, or enter into a joint venture with a foreign firm. In this case, the affiliate abroad can provide the service. Most of the affiliate's labor requirements will be met locally, although some skilled workers or managers may also move for a time period from the United states to the site of the foreign affiliate. In both trade and affiliate sales, there is a link to the U.S. firm, but sales abroad of U.S. affiliates do not necessarily entail a specific transaction between a U.S. resident and a resident of another nation and thus may not enter directly into the U.S. balance-of-payments accounts.

However, exporting and affiliate sales are not mutually

16 Most analyses of international competition in services exclude factor services, i.e., the employment abroad of a country's labor or capital by a foreign'firm. 
exclusive modes of participation in foreign markets. In fact, they are often complementary activities of multinational corporations. ${ }^{17}$ Likewise, trade and factor movements, or exports of goods and exports of services, have significant complementarity in actual transactions. The potential links among alternative modes of competition in foreign markets are highlighted in the following comparison, adapted from Feketekuty and Krause (1986), of the foreign sale of an automobile (tangible good) and of insurance (service). In both instances, movement abroad of U.S. factors, establishment of a foreign affiliate, and exporting are all potentially present.

To sell automobiles abroad, the U.S. producer usually establishes a dealer network in the foreign market. The U.S. firm need not own the dealerships, but in practice often does so. The firm also sends sales representatives to the foreign market to negotiate the terms under which the cars will be sold, government relations representatives to persuade foreign governments that safety and environmental standards have been met, and engineers to train and advise local mechanics. The automobiles themselves may be exported from the United States or produced by a local subsidiary. Often, market penetration begins with exporting and may be followed by establishment of a local subsidiary. Even then, the local operation may simply assemble automobiles from parts imported from the United States.

The U.S. insurance company wishing to sell policies abroad

17 See Bergsten, Horst, and Moran (1978, Chapter 3). 
will likewise require a dealer network of local insurance brokers or agents to sell and service the policies. Again, the U.S. company need not own the brokerages but may do so. The U.S. insurance company will likewise need to send government relations managers to satisfy the foreign government that local regulatory requirements have been met, sales representatives to deal with local brokers, and perhaps management consultants to help train the local brokers.

For both automobiles and insurance, what is "exported" conceptually to the foreign market represents just a fraction of the value of the purchase made by the final consumer. Value added by local inputs, including sales and service personnel and transportation, make up the difference. In the case of insurance, what is exported by the U.S. company is mainly risk-bearing and related industry know-how, as well as other "headquarter services" of the parent corporation.

Attempting to classify any given transaction as either an export or an affiliate sale may thus produce a distorted overall picture of international competition. A more appropriate question concerns the relative importance of the two modes of foreign competition. The extent to which a given foreign transaction is carried out through affiliate sales rather than exporting obviously depends on technology but is also influenced by a variety of government policies toward trans-border flows of products and data, movements of people, and direct foreign investment. Such policies at home and abroad may have a minor influence on the global market 
share of a given firm but a major influence on the firm's primary mode of participation in foreign markets.

\section{Comparative Advantage in Services}

Comparative advantage is the basic determinant of the direction of trade and of the gains from trade among nations: nations export the goods they can produce relatively cheaply and import goods that are relatively more costly to produce at home. Trade can thus be viewed as a superior indirect technology for producing certain goods. A given supply of primary inputs yields a greater total value of outputs when resources are concentrated in activities that are relatively more efficient.

Conceptually, comparative advantage may rest on differences in relative factor abundance, differences in technology, or the existence of scale economies. Most of the literature on merchandise trade has focused on the role of relative factor abundance. When countries have similar tastes and technologies, each will tend to export goods making relatively intensive use of its abundant factors and import goods requiring large amounts of its scarce factors. ${ }^{18}$

18 The theory of comparative advantage explains the source of mutual gains to nations from international trade and, in particular, shows that a nation can gain from trade even if it is at an absolute disadvantage in all productive activities. The theory of comparative advantage does not suggest that every resident of a given nation will be made better off by trade. Actual trade flows are determined by international competitiveness, of which comparative advantage is just one element, along with exchange rates and national policies. Comparative advantage is a reliable predictor of a nation's trade flows only when exchange rates are consistent with globally balanced trade and the influence 
Accordingly, U.S. comparative advantage should lie in the high-technology areas, as these employ large amounts of skilled labor, the nation's abundant resource. Extending the same approach to services, there is a similar presumption that U.S. comparative advantage will lie in the high-technology end of the spectrum, and particularly in the production and export of knowledge itself.

However, recent theoretical research has emphasized the potential role of economies of scale in determining trade flows and the gains from trade. With restricted trade, large countries will tend to have lower prices for goods and services subject to important economies of scale. ${ }^{9}$ But these lower prices do not necessarily predict the direction of trade when barriers are removed; with integrated markets, a firm located in a small nation no longer operates, at a cost disadvantage.

Moreover, while scale economies increase the potential benefits from liberalization, they also complicate the issue of how these benefits are shared. In particular, the possibility that a given nation may lose by expanding trade even though global efficiency is improved is more difficult to rule out when scale economies are important. Mutual gains are assured only if each country is able, on average, to expand production in industries

of trade-distorting policies is minor.

19 Large refers here to the size of the market for a given product. This tendency has been termed "false comparative advantage" by Lancaster (1980). Also see Helpman and Krugman (1985, 152). 
with scale economies. ${ }^{20}$

Information-based and knowledge-based services are the areas in which U.S. firms and U.S. policymakers seem most confident of expanding global sales. These services are likely to exhibit strong economies of scale. The theoretical analysis of comparative advantage and gains from trade suggests both that the apparent U.S. advantage in these industries (as measured by domestic prices) may be overstated under current conditions and that the cautious approach of other nations toward the liberalization of trade in services may have a firm economic basis.

20 This problem was discussed by Erank Graham more than half a century ago. For a modern treatment, see Helpman and Krugman (1985). 
IV. Services in the Domestic Economy

This section reviews evidence on the growing importance of services in U.S. employment and production, and compares U.S trends with experience of other nations. Tables 3-8 indicate the division of U.S. economic activity into service and non-service components according to two alternative criteria. As discussed below, the most important categories of internationally traded services (see Tables 1 and 2 ) are not the same ones that are most important in terms of recent growth of domestic employment.

\section{Services in U.S. Employment}

Sectoral employment is the yardstick that demonstrates most clearly the extent to which the United States has become a "postindustrial" or service economy. Tables 3 and 4 show recent nonagricultural employment of U.S. workers by type of industry. The service-producing sectors are distinguished here by the intangible nature of their output and include both final-demand and intermediate-input categories.

As Table 3 shows, U.S. employment is now heavily concentrated in the industries broadly described as service-producing: transportation, public utilities, wholesale and retail trade, finance, insurance, real estate, miscellaneous business services, health, and government. This broad range of activities comprises all industries that are not included in the goods-producing sector, i.e., manufacturing, construction, mining, and agriculture. The employment classification in Table 3 is on the basis of the 
industry's main output, which may be sold to final consumers (health, education), used as an intermediate input (business services), or both (restaurants).

Tables 4 and 5 indicate the nation's labor-force allocation in longer-term perspective. Table 5 shows the division of U.S. employment among three major sectors: agriculture, goods, and services. Here agriculture includes forestry and fisheries; goodsproducing employment includes mining and construction. Government employment is allocated according to industry, with only public administration 1 isted as a separate service category.

Table 5 reveals that the growth of service-sector employment as a share of the U.S. labor force is a trend going back to 1850 , the earliest year for which data are available. However, until recent years that growth was accommodated mainly through the secular contraction of agriculture's share. Agriculture accounted for about two-thirds of U.S. employment in 1850 but less than four percent by the 1980s.

In contrast, the share of goods-producing employment increased steadily until the turn of the century and moved cyclically around the one-third mark for many years thereafter. Only in the past twenty years has growth of employment in service-producing industries come mainly at the expense of manufacturing and the other non-agricultural goods-producing sectors.

Even so, it is primarily the share of the goods-producing sectors in total employment, rather than the level of such employment, that has fallen in recent years. As Table 6 indicates, 
the number of workers in goods-producing employment actually rose between 1967 and 1979, even though the share of these sectors fell from 34.7 percent to 30.2 percent of the U.S. Iabor force. But a sharp recession in 1980-1982 produced a substantial fall in goodsproducing employment. Although employment growth resumed in 1983, by 1986 the total number of workers in the goods-producing industries was still well below previous peaks. Of course, employment in manufacturing and other goods-producing sectors fell even more relative to the levels that would have been attained had the distribution of the larger labor force among the major sectors remained unchanged from the 1967 pattern.

\section{Services in Gross National Product}

A similar pattern emerges from an examination of U.S. gross national product (GNP) by industry, as shown in Table 7 . In current dollars, the service-producing sectors now account for over two-thirds of U.S. GNP, up from about 55 percent immediately after World War II. The industrial classifications used in Tables 3-7 include both intermediate and final products, and both government and private activities.

An alternative measure of the economic importance of services is their share in final demand as measured by consumer spending. As shown in Table 8, expenditure for services now accounts for about one-half of total personal consumption expenditures, up from about 40 percent in 1929 and as little as one-third in 1950. The main categories of service expenditures in final demand are 
housing, utilities and other services used in household operation, transportation, and medical care. ${ }^{1}$ However, these data tend to understate the relative importance of services in final consumption, since they do not include important governmentfinanced consumption services such as education and recreation.

\section{Why and How Services Grew}

The summary tables presented above document the evolution of today's "service economy" but give little insight into the causes of these dramatic changes. In brief, the employment and output shifts reflect the combined impact of three basic forces: changes in the sectoral allocation of final demand (in turn reflecting rising per-capita income and systematic changes in relative prices as well as demographic shifts), relative rates of productivity improvement, and changes in the organization of economic activity.

Looking first at the long-term shift of employment out of agriculture offers some perspective on the more recent movements from goods-producing to service-producing employment. In the case of agriculture, low income and price elasticities of demand, changing dietary preferences, and sustained high rates of próductivity improvement have all contributed to agriculture's declining share of total employment, even over the periods when the United States was increasing its penetration of foreign markets.

Changes in the organization of economic activity reinforced

21 Housing services in Table 8 include the imputed rental value of owner-occupied housing, but transportation services does not include a similar imputed value for motor vehicles. 
the effects of demand and productivity changes, with specialized processing, transportation, distribution, and business-services units gradually taking over many functions once handled by workers classified as agricultural employees. But the nation is by no means losing its "agricultural base" in terms of production. On the contrary, agricultural outputs have continued to grow with dismaying rapidity despite the steady decline in the number of workers employed in the sector.

While the shift from goods-producing to service-producing employment is more complex, some of the same forces were important. Changes in the age composition of the population and in the laborforce participation of women have fueled increases in the demand for some services that have experienced high rates of growth. These include health and education among professional services, and eating and drinking establishments, a major component of retail trade. Moreover, the goods-producing sectors have maintained relatively high rates of productivity increase, so that outputs of most sectors have continued to rise even when employment has stabilized or dipped. Einally, changes in the degree of vertical integration of goods-producing firms has led to a reclassification of many workers from other industrial categories as service employees although the work performed by these employees is basically unchanged.

In recent years "business services" has been the most rapidly growing sector of the U.S. economy in terms of employment. The 
business services sector comprises seven major industries: ${ }^{2}$ advertising; consumer credit reporting and collection; mailing, reproduction, and stenographic services; services to buildings, including cleaning, maintenance, and exterminating services; personnel supply services, including both temporary-help suppliers and employment agencies; computer and data processing services; and miscellaneous business services, which include research and development, management and consulting, and protective services.

Firms in this industry provide a variety of business services on an ongoing contractual basis (e.g., janitorial services, data processing, advertising) or to accommodate temporary or cyclical requirements (e.g., office personnel, unskilled labor). While some of the included activities are new (computer services), the growth of others reflects, changes in the way U.S. firms are doing business and particularly in employer-employee relationships in the goodsproducing sectors of the economy. ${ }^{23}$

4. Services, Labor Supply, and Productivity

Changes in the composition of the labor force may affect

22 This definition is the one used in the employment data published by the Bureau of Labor Statistics. "Business services" is sometimes defined more broadly to include all services purchased mainly by businesses rather than households, adding in particular business-oriented financial and communcation services. Also, the U.S. Department of Commerce uses the term "business services" in its balance-of-payments reporting to refer to all nonfactor services traded internationally.

23 Like the broader services category, employment in business services includes workers at every level of skill. See Howe (1986) for a detailed assessment of employment growth in the business services industry. 
growth of service employment through changes in productivity as well as through changes in the pattern of final demand. The recent bulge of new entrants into the labor force was absorbed in large part through expansion of employment in the services sector, with slow or negative increases in compensation. One recent study found that women hired in the service sector were much more likely not to have worked at all in the previous year than to have worked previously in the goods sector. ${ }^{24}$. The rapidly growing retail-trade sector (which includes the infamous fast-food outlets) experienced the largest relative decline in average hourly earnings between 1977 and 1983 of any major employment sector. ${ }^{25}$

With fewer new entrants to the labor force, or with greater downward rigidity of wages and employee benefits (as in the European Community), a smaller number of new jobs would have been created in services, while the higher cost of employing additional workers would have induced employers to adopt more capitalintensive (i.e., more "productive") technologies. ${ }^{26}$

The relatively strong productivity performance and accordingly

24 Urquhart (1984). Men hired in the service sector were more likely to have worked in the goods-producing sector rather than not working at all during the previous year.

25 U.S. Department of Labor, Handbook of Labor Statistics, June 1985, Table 78 .

26 A related issue is the extent to which firms in service industries earn rents, which are shared with workers through higher wages. Using micro data, Krueger and Summers (1986) show that most service industries are low-paying even when the usual adjustments are made for worker characteristics. The exceptions include banking and insurance, industries that are characterized by substantial barriers to entry. 
low employment growth of the goods-producing sectors may have a similar explanation. With more extensive unionization and less flexibility in compensation and work rules, faster adaptation of new labor-saving technologies would typically mean slower employment growth but higher measured increases in labor productivity for any given growth rate of output. Thus, for both tangible goods and for services, sectoral patterns of labor productivity growth are appropriately viewed as endogenous, reflecting the interaction of such forces as technological advance, labor-market developments, and tax policy.

\section{International Comparisons}

The relative importance of the U.S. service sector in total employment has increased over time with the nation's rising percapita income. Cross-country evidence also points to a strong positive correlation between service employment and per-capita GNP. As Table. 9 shows, in 1981 service employment absorbed just 15 percent of the labor force of the world's poorest countries, while agriculture occupied nearly three workers of every four -- a pattern not too different from the United States in the mid1800 s. $^{27}$

27 Final demands are typically met by a combination of goods and services selected on the basis of both income and relative prices. Intermediate-input service needs are met by direct employment or by purchases from specialized service-providers. Again, the choice depends on relative prices. The observed longterm correlation between per-capita income growth and the importance of service employment necessarily reflects changes in relative prices as well as systematic effects of rising income (Kravis 1983; Kravis, Heston, and Summers 1983). The same is of 
Among the industrialized nations, the average share of service employment was 58 percent, with the United States eight percentage points higher. Moreover, between 1965 and 1980, every industrialized country showed an increase in the share of services in total employment. The same was true also for the nonmarket economies of Eastern Europe and of almost all other nations, whether rich or poor. In most cases, the increase in the share of services has come at the expense of agricultural employment, presumably reflecting the dissemination worldwide of modern agricultural technologies as well as the industrialization goals of many nations. ${ }^{28}$

A similar pattern emerges for the percentage share of services in gross domestic product (GDP). As Table 10 indicates, the percentage share of services in GDP averaged 62 percent in 1984 for the industrialized nations but only 29 percent for the world's poorest nations. The table also shows that the share of services has been increasing over time for every industrialized nation, while that of industry broadly and of manufacturing specifically has been declining.

These shares are calculated on the basis of local domestic prices. However, prices of services tend to be higher relative to those of tangible goods in countries with higher per-capita GNP.

course true for cross-country comparisons in a given year.

28 Some developing nations are belatedly recognizing their strong comparative advantage in agricultural production as well as the concentration of poverty in rural areas. A few are attempting to alter domestic policies that have favored industrial production at the expense of agriculture. 
When a common set of international prices is used to value outputs, the percentage shares of services in GDP differ less markedly over time for a given country or between rich and poor nations in a given year. Using real-quantity indices in place of value shares, Kravis, Heston, and Summers (1983) show that in real terms, lowincome countries may actually consume services in higher proportions than wealthier nations. This finding presumably reflects the very low relative prices of services in poor countries. 


\section{International Service Transactions}

The high priority placed by the United States on negotiations on trade in services is frequently justified by assertions that this trade is currently or potentially very important to the nation's overall international position. Yet the data on U.S. trade in services provide only weak support for such a claim. Globally and also for the United States, the aggregate size of services trade as reflected in balance-of-payments data is roughly one-fourth that of merchandise trade. Moreover, that proportion has been relatively stable in recent years. Thus, neither the absolute size nor the rate of growth of trade transactions in services by themselves make a compelling case for its recent promotion to a top position on the trade policy agenda of the United States.

Although there is ample reason to believe that official trade data seriously underestimate the true value of both U.S. service exports and imports, even improved and expanded services data do not provide credible support for a major push on services trade. If there is a strong argument for broad-based negotiations on services, it appears to lie less in trade than in the alternative mode of international competition, sales abroad of U.S. affiliates.

Tables 11 and 12 show the value and composition of international service exports in 1980 for the 25 leading serviceexporting nations. The United states is indeed largest in terms of services exports, as well as of merchandise exports and income from foreign investment. However, the relative importance of services, 
as measured by the ratio of service exports to GDP, is less for the United states than for most of the other nations. This should perhaps not be surprising, given the very large absolute size of the U.S. market. But the ratio of service exports to merchandise exports is also far below that of other major service exporters.

still, these data provide only a partial indication of the importance of international competition in services to the U.S. economy. As described in Section III, a U.S. firm may compete in markets abroad through direct exports or through a foreign affiliate. A service export entails production by U.S. residents of a service purchased by the resident of another nation. At least in principle, the total value of service export sales appears in the services section of the U.S. balance-of-payments accounts. ${ }^{29}$ As shown in Table 12, the most important service export categories by value for the United States and most other nations are travel and transportation.

Unlike export sales, sales abroad of U.S. affiliates do not enter directly into the U.S. international accounts, as such sales do not necessarily entail a specific transaction between a U.S. resident and a resident of another nation. Affiliate sales

29 In practice, many service exports are misreported or unreported. Some service exports are bundled together with merchandise exports (e.g., computer equipment and software). For these, the total value of the bundle is reported as a merchandise export. In others including tourism, reported amounts are based on voluntary surveys with low response rates. Some categories of service exports are estimated from conceptually flawed or incomplete data, while still others are simply omitted. For further details on measurement issues, see office of Technology Assessment (1986) and references cited there. 
probably have important indirect effects on two items in the services section of balance-of-payments accounts, earnings of U.S. investments abroad and intra-firm payments of royalties and licensing fees. But neither item provides a reliable measure of the U.S. stake in the foreign market, as payments between the parent and foreign affiliates are shaped by tax considerations and other dimensions of national regulation.

For the firms and industries that have shown the greatest interest in a U.S. initiative on services trade, sales abroad by foreign affiliates are substantially larger than exports from U.S. operations, although the industries' own discussions typically do not distinguish these two types of foreign operations or divide revenues from foreign markets into exports and affiliate transactions.

The importance of subsidiary sales in total foreign sales of U.S. service firms is qualitatively similar to the situation of international competition in tangible goods. In the manufacturing industries, U.S. firms have maintained a roughly constant share of world exports in recent decades. But exports from the United States have constituted a declining share of total U.S. sales in international markets, with exports from U.S. affiliates abroad increasing to maintain overall constancy of the total market share. ${ }^{30}$

In the case of services, available data are sketchy for both exports and foreign sales. One estimate suggests that revenues

30 Kravis and Lipsey (1985, 1986). 
from sales abroad of U.S. affiliates exceed those from U.S. exports on average by about fifty percent (Office of Technology Assessment, 1986). Since profit rates of foreign subsidiaries are usually higher than those of domestic operations, this would mean that, in terms of profits to U.S. firms competing internationally, affiliate sales probably account for well over half of all profits generated by operations abroad. However, affiliate sales translate into a smaller demand for domestic labor input than the same dollar volume of export sales.

The importance of affiliate sales relative to direct exporting varies substantially across those industries with important international transactions. For some major service industries, including travel, educational and legal services, and technology licensing, direct exports account for nearly all revenues from international transactions. In a second group, including insurance, advertising, and accounting, affiliate sales provide the bulk of foreign revenues. For a third group, including transportation, construction, consulting, and computer software, both direct exports and affiliate sales are significant. Table 13 shows office of Technology Assessment estimates of 1983 revenues in both categories for U.S. service firms. Banking, an important service industry both domestically and in international transactions, was treated separately because of the special problem of distinguishing investment income from the service component of foreign revenues.

Given that affiliate sales greatly exceed exports for many 
service providers, a broader measure of the importance of international transactions to U.S. service industries is the size of total foreign revenues from both sources relative to overall sales. For the major U.S. service industries as ranked on the basis of domestic employment, including health services and education, foreign revenues from exporting plus affiliate sales are small relative to the value of total output. Moreover, as with merchandise trade, a few large firms account for the lion's share of all U.S. international service transactions in a given industry. While there is no "typical" service sector, the insurance industry can provide an illustration of the relative magnitudes. According to stalson (1985, 94), there are about 10,000 insurance companies worldwide, with half of those in the United States alone. But only a few hundred have significant foreign sales. Of this group, about 50 are U.S. firms; among the U.S. firms, five are very large and operate in many countries. Revenues from foreign sales constitute about one-tenth of total revenues for the U.S. industry, with most of that going to five firms.

Although the data for many service industries are seriously deficient, a more significant problem is in interpretation. None of the available measures can give an accurate indication of the contribution of foreign sales to profits. For information-based service industries, including telecommunications and most business services, fixed costs may account for a very large portion of total costs. Expansion into foreign markets (whether through exports or sales of affiliates abroad) may thus make a contribution to profits 
far in excess of the proportion of foreign sales to total

revenues. ${ }^{31}$ of course, the actual or potential contribution to profits of U.S. firms is still far from a measure of the national stake in pursuing multilateral liberalization of barriers to international competition in the service sector. This is particularly relevant at a time when attaining U.S. goals will surely require trade concessions affecting the prospects of other domestic industries.

${ }^{3} 1$ The existence of scale economies is, of course, not unique to for-profit activities. Both health and education, largely organized on a not-for-profit basis, offer similar examples of potential benefits from "exporting" services in excess of the share in total revenues. 


\section{Barriers to International Competition}

The U.S. move to promote inclusion of services in the new round of GATT negotiations reflects the belief not only that international service transactions are important to the American economy but also that significant barriers hamper the access of U.S. firms to foreign markets. This section considers the types of barriers that might be included in efforts to maintain open markets for services transactions, and prospects for success based on experience in negotiating limits on barriers to merchandise trade.

\section{Barriers to Merchandise Transactions}

Even for the relatively straightforward case of tangible goods, barriers to trade are anything but straightforward. Tariffs, the classic trade barrier, have not entirely disappeared, and high tariffs are still present for some products. However, in recent decades focus has shifted to "non-tariff barriers" (NTBs) to trade, meaning all other national policies that potentially affect the volume of and gains from international trade. The Kennedy Round of GATT negotiations succeeded in slicing most tariff rates to postwar lows. The subsequent Tokyo Round was the first to tackle the much broader issue of nontariff barriers, but with only modest results.

At least four major reasons account for the slow progress. First, NTBs are not one problem but fifty or three hundred separate problems, ranging from relatively straightforward quantitative trade restrictions to such complex mechanisms as product standards, 
government procurement procedures, and labor-market policies. In most cases, the impact on foreign competition is not the primary motivation of the policy, although in practice such policies are nonetheless administered in a way that puts foreign firms at a disadvantage in serving the local market.

A second reason for slow progress in limiting the proliferation of nontariff barriers is that their use arises partly from basic deficiencies of the GATT structure in handling problems of adjustment to changing international conditions. For example, the widespread use of "voluntary" export restraints (VERs) reflects general dissatisfaction with the provisions of Article XIX, which in principle governs members' response to unanticipated changes in international competition.

Third, the GATT was designed under the assumption that national policies can be viewed as having both "domestic" and "international" components. The GATT rules focus primarily on the latter - i.e., policies applied at the national border. But the increased integration of national markets has made this dichotomy almost obsolete.

Finally and perhaps most important, both the GATT negotiation process and the GATT rules are predicated on a mercantilistic view of the gains from international trade, i.e., that the "gains" from open markets are expanded exports and that any increased imports represent the price paid for the opportunity to expand exports. By failing to emphasize the real mutual gains from integrated global markets, GATT member nations have shifted negotiating efforts in 
inappropriate directions, even to the point of forcing GATT to become a party to global cartelization of the markets for textiles and apparel. ${ }^{32}$

Unfortunately, the factors that apply to merchandise trade are at least equally relevant for international competition in services, where movement of "traded" products across national borders is the exception rather than the rule. This does not necessarily imply that inclusion of services in forthcoming negotiations is unprofitable. It does, however, mean that the very basic problems now confronting the GATT are likely to be exacerbated rather than eased by broadening its mandate to include services.

\section{Barriers to Competition in Services}

Diverse in many respects, the service industries do not share common objectives with respect to expansion abroad. Indeed, some industries with well-established foreign operations are hesitant to participate in a generic sectoral push to expand market access abroad lest their own firm-specific and industry-specific needs receive less favorable attention from foreign governments. Even information on the relative importance of particular types of barriers is not easily collected. Some U.S. firms are reluctant to divulge information that might indicate their competitive position to foreign or domestic rivals, and the service firms as a group are

32 The small GATT secretariat has remained an important voice for liberal policies, but these efforts have had scant influence on
the actions of major nations. 
less accustomed than those in the goods-producing sectors to providing detailed information about their business operations to government agencies on a regular basis (International Trade Commission 1982,1$)$.

To provide better support for U.S. efforts, the International Trade Commission conducted a voluntary survey of 479 international service firms in fourteen service industries. Only about onefourth of the firms responded to the survey, and the response rate was much lower in some industries. In communication services, only one firm out of eight responded to the questionnaire.

Respondents identified the degree to which specific nontariff barriers were encountered in foreign markets. Most important were restrictions affecting the basic "right of establishment" in the foreign market ( $63 \%$ of all respondents), specific barriers to provision of a service by foreign firms (62\%), and foreignexchange controls $(54 \%)$. Other barriers in order of frequency included government procurement (30\%), technical issues (27\%), restrictions on related trade in goods $(21 \%)$, subsidies and countervailing duties $(21 \%)$, licensing requirements $(18 \%)$, standards and certification $(17 \%)$, inadequate protection of intellectual property $(12 \%)$, and professional qualification restrictions $(10 \%)$.

Despite the ubiquitous nature of these barriers, one-fourth of the firms did not anticipate any increase in foreign revenues from their removal. Presumably profits would rise, however. Half of the firms surveyed did expect revenues to increase, but the 
anticipated increase was surprisingly small - \$I billion in total, plus another $\$ 2$ billion in associated merchandise trade exports. ${ }^{3}$

\section{Why Liberalization Is Opposed}

Looking at specific barriers and speculating on the prospects for limiting their future use ignores the more basic question of why most countries have responded coolly to U.S. proposals for liberalization of trade in services. If the experience with merchandise trade is indicative, agreeing to eliminate specific barriers without regard to their domestic objectives usually means that other policies, possibly less desirable from an efficiency perspective, will be substituted in short order.

Obviously, all the same kinds of economic and political considerations - employment, adjustment, regional effects, etc. that arise with liberalization of merchandise trade are equally relevant for trade in services. But some additional domestic considerations appear to be more important for services as a group than for goods.

First, many types of services, from banking and telecommunications to haircuts and restaurants, are subject to extensive local regulation, either because they are considered essential to national welfare and security or because they have important potential effects on consumer health and safety. Whatever their motive, regulatory barriers typically ensure above-

33 International Trade Commission (1982, 4-7). This document also provides information by industry for each of the fourteen
service industries. 
normal profits for successful entrants, making current domestic providers particularly reluctant to share the market and potential foreign providers particularly keen to enter.

Moreover, local regulation is likely to act as a barrier to international competition even when the regulation is applied evenhandedly to both domestic and foreign firms; the same requirement is often more difficult and costly for a foreign firm to meet because of language barriers or general unfamiliarity with local legal and administrative procedures. But regulation often does discriminate explicitly between domestic firms and foreigncontrolled suppliers.

Eor some particular sectors deemed "essential," a foreign presence is considered undesirable or even unacceptable. For example, the United States prohibits foreign ownership of radio and television stations, while Brazil and Japan exclude foreign firms in some telecommunications sectors. Many countries provide essential services via a public monopoly. Even the United States maintains a government monopoly in postal service.

For such sectors there are really two different cases for excluding foreign firms. In some instances a nation may desire to maintain permanent local control over a particular sector, even if this control comes at a cost in terms of efficiency. Presumably a national-security motive is present in most such cases. For a second group, the need "temporary" protection is justified by a variant of the usual infant-industry argument.

The perceived need to protect infant service industries is an 
important factor underlying the strong resistance of some developing nations to GATT negotiations on services. Financial services as well as telecommunications and associated informationbased services are frequently protected, with the goal of nurturing a domestic provider not yet able to confront international competition. However, because these services are important intermediate inputs, protection raises costs and lowers efficiency for all the using industries, thus lowering the odds of survival for other, perhaps more promising, infants.

But as noted in section III, it is theoretically possible for liberalization to reduce national welfare unless a country is able on average to expand its outputs in activities with scale economies. This condition is unlikely to be met for most developing nations, so that the theoretical case for developingcountry liberalization of service sectors is not airtight.

Finally, some countries generally concerned about foreign influence within their borders see liberalization of "trade" in services as the start of a general assault on national policies restricting direct foreign investment. Their alarm has some justification, since U.S. firms pressing for expanded markets abroad rarely distinguish between opportunities for trade and opportunities for affiliate sales.

Overall, as in the case of merchandise trade, a variety of arguments may be used to justify barriers against foreign competition in service sectors. But, as in the case of merchandise trade, the "national interest" arguments for continued protection 
50

are put forward mainly by those whose own commercial interests would be threatened by liberalization. 
VII. Where and How to Negotiate on Services

Although the United States has succeeded in putting the services issue on the agenda for the new GATT round, many questions concerning future U.S. negotiations in this area remain to be answered. This section considers two. First, what are the merits of pursuing the services issue in other bilateral or multilateral forums, in addition to or instead of the GATT? Second, what are the alternative strategies that might be used to make progress on this admittedly difficult issue?

\section{Where to Negotiate on Services}

As a practical matter, it is too late to wonder whether the United States is prepared to lead international negotiations on service issues in the GATT. ${ }^{4}$ For better or worse, the decision has been made and cannot be reversed without substantial loss of credibility for the United States. Gaps in knowledge, both analytical and empirical, remain significant but are beginning to be filled. However, the Uruguay Round of GATT negotiations is expected to extend over a number of years. In the meantime, what might be accomplished by pursuing some of the same issues with selected trading partners in other forums?

Since progress on service issues will require countries to grapple with a whole new set of nontariff distortions of international commerce, bilateral negotiations offer an opportunity

34 Krommenacker (1984) provides an insider's evaluation of the potential role of the GATT in liberalizing trade in services. 
to explore these issues with just one partner. In the case of Canada, where broader bilateral negotiations on a free-trade area are already in progress, there is a natural opportunity to test out possible negotiating strategies. One special complication in this case is Canada's provincial regulatory structure. However, given the generally cordial relationship between the United states and Canada and the high degree of integration of the two economies, any approach that fails in this test case can probably be scrapped without trying it out in the GATT.

A second possibility is to work initially within a group of countries with a particular interest in pursuing liberalization in the services area. This has been termed a "mini-lateral" approach or a "GATT of the like-minded." Since the developing nations have expressed the greatest reservations about services, such a group would presumably be drawn from the OECD, or the OECD might become the formal sponsor of a parallel negotiation. ${ }^{5}$ Agreements reached within the group would have a conditional most-favored-nation (MFN) status, applying only to the nations agreeing to abide by the terms. ${ }^{36}$ However, others could join the group later by agreeing to the same terms.

35 The OECD has already sponsored considerable consultative work on services. See Schott (1983) for an evaluation of OECD initiatives and the relative merits of proceeding within the OECD rather than the GATT.

36 Such conditionality represents a departure from the central GATT principle of MFN treatment (nondiscrimination), under which tariff concessions made by any member apply to all other members. However, a similar appraoch was used in the Tokyo Round for the codes of conduct on specific types of nontariff barriers. 
While the benefits of learning-by-doing in a smaller negotiation are real, there are some risks as well. Bilateral or minilateral negotiations create preferential trading arrangements that become vested interests. This may reduce the motivation of some GATT members to press for broader and more inclusive agreements later on (Aho and Aronson, 1985). Another danger is that the terms of a bilateral agreement with, say, Canada, may be difficult to extend to other trading partners with stronger comparative advantage in certain sectors (e.g., transport, construction).

\section{How to Negotiate on Services ${ }^{37}$}

Here the basic choice is whether to organize the discussions along sectoral lines (e.g., insurance, telecommunications) or to attempt as in the Tokyo Round to develop codes that cover particular types of policies (e.g., subsidies, government procurement policies) for all or most types of traded services. Given the vast universe of policies that impinge on international services competition, it is not possible to handle all relevant issues through the second approach, so the question is really about the degree of emphasis accorded to each.

One strategy to prevent the task from becoming unmanageable is to begin by extending as far as possible the current GATT framework on merchandise trade to services transactions. This

37 Strategies for negotiating on services are discussed in greater detail by Aronson and Cowhey (1984), Brock (1982), Gray (1983), Malmgren (1985), Stalson (1985), and Sapir (1985). 


\section{4}

approach would identify any "easy" liberalization gains from moving negotiating efforts into virgin territory. At the same time, information would be gained about the important specific issues that do not fall easily into a framework paralleling that for goods.

Another important issue is the extent to which liberalization in service trade is linked to issues on goods. The two-track compromise agreed on at Punta del Este suggests that linkage will be minimal, at least at the start. Unfortunately, complete separation places limits on the efficiency gains attainable through multilateral negotiations, and especially potential North-South agreements to make liberalization in labor-intensive manufactured goods in the North the quid pro quo for high-technology and services liberalization in the South.

One final strategic issue concerns timing. The conventional wisdom is that the pressure of deadlines and media attention can help negotiators to reach mutually beneficial compromises that might otherwise prove elusive. With perhaps a decade of slogging through difficult issues ahead, there is need for some short-term goals where progress can be made, and announced, sooner. 
VIII. Summing Up

The United States has indeed become a "service economy" -- and so have most U.S. trading partners, both industrialized and developing. But although domestic employment at home and abroad is now heavily concentrated in the service industries, tangible goods still dominate international trade. Moreover, the services that absorb most of the labor force at home are not the same services that account for most international service transactions nor even the ones ripe for global expansion in the near future.

Thus, the need to press forward on liberalization of services must be justified along other lines -- e.g., to maintain the forward momentum in multilateral negotiations, or to restore domestic support in the United States for open international markets. Yet these arguments seem shaky if services are allowed to displace important unfinished business in the traditional areas of GATT efforts, especially safeguards. Also, if U.S. service firms are interested mainly in expanding sales abroad of their foreign affiliates rather than exports, as the greater importance of the former in total revenues suggests, then the resulting base for domestic support may be rather narrow.

But there are important positive aspects to bringing services into the GATT. Despite its sometimes disappointing record, the GATT remains the only international organization where rules are taken seriously.38 Because services would be a new issue in the

38 Not necessarily followed, but at least taken seriously. A good example is the prolonged effort by the United States to find a "GATT-able" variant on its Domestic International Sales Corporation 
GATT, there could be some easy gains to be made initially; in merchandise trade, only the hard things are left to tackle. Consideration of services would necessitate greater attention to the links between trade and direct investment and between trade and international movements of labor -- further complicating the task of GATT, but in a way likely to serve its ultimate objective of pushing the world economy toward greater efficiency. And, finally, because goods and services are inextricably (and increasingly) intertwined in real transactions, progress on merchandise trade will surely be slowed unless trade negotiators begin to think seriously about services too.

(DISC) device for subsidizing exports. 


\section{REFERENCES}

Aho, C. Michael, and Jonathan David Aronson. 1985. Trade Talks. New York: Council on Foreign Relations.

AFL-CIO, Industrial Union Department. 1984. Deindustrialization and the Two Tier Society: Challenges for an Industrial

Policy. Washington: Industrial Union Department, AFL-CIO. Aronson, Jonathan, and Peter Cowhey. 1984. Trade in Services:

A Case for Open Markets. Washington, D.C.: American Enterprise Institute.

Bergsten, C. Fred, Thomas Horst, and Theodore H. Moran. 1978. American Multinationals and American Interests. Washington, D.C.: Brookings Institution.

Bhagwati, Jagdish. 1984. Splintering and Disembodiment of Services and Developing Nations. The World Economy. $7: 133-144$. Brock, William A. 1982. A Simple Plan for Negotiating on Trade in Services. The World Economy 5:229-240.

Deardorff, Alan V. 1985. Comparative Advantage and International Trade and Investment in Services. In Trade and Investment in Services: Canada/US Perspectives, ed. Robert M. Stern. Toronto: Ontario Economic Council. Feldman, Robert A., and Allen J. Proctor. 1983. U.S.

International Trade in Services. Eederal Reserve Bank of New York Quarterly Review 8, no. 1, 30-36.

Eeketekuty, Geza, and Lawrence B. Krause. 1986. Service and High Technology Goods in the New GATT Round. In Pacific Trade Policy Cooperation: Goals and Initiatives. Korea Development Institute, 87-99. 
Gray, H. Peter. 1983. A Negotiating Strategy for Trade in Services. Journal of World Trade Law 17:377-387.

Helpman, Elhanan, and Paul R. Krugman. 1985. Market Structure and Foreign Trade. Cambridge, MA: MIT Press.

Howe, Wayne J. 1986. The Business Services Industry Sets Pace in Employment Growth. Monthly Labor Review 109 (April) 2936.

Kravis, Irving B. 1983. Services in the Domestic Economy and in World Transactions. National Bureau of Economic Research Working Paper no. 1124, May.

Kravis, Irving B., Alan W. Heston, and Robert Summers. 1983. The Share of Services in Economic Growth. In Global Econometrics: Essays in Honor of Lawrence R. Klein, ed. $F$. G. Adams and B. Hickman. Cambridge, MA: MIT Press, 188218.

Krommenacker, Raymond J. 1984. World-Traded Services: The Challenge for the Eighties. Dedham, MA: Artech House. Krueger, Alan B., and Lawrence H. Summers. 1986. Reflections on the Inter-industry Wage structure. Harvard Institute of Economic Research Discussion Paper No. 1252, July.

Kutscher, Ronald E., and Valerie A. Personick. 1986. Deindustrialization and the Shift to Services. Monthly Labor Review 109 (June) 3-13.

Lancaster, Kelvin. 1979. Variety, Equity, and Efficiency. New York: Columbia University Press.

Lawrence, Robert Z. 1984. Can America Compete? Washington, D.C.: Brookings Institution. 
Lipsey, Robert E., and Irving B. Kravis. 1985. The Competitive

Position of U.S. Manufacturing Firms. Banca Nazionale del Lavoro Quarterly Review 153:127-154.

Malmgren, Harald B. 1985. Negotiating International Rules for Trade in Services. The World Economy 8:11-26.

Office of Technology Assessment, United States Congress. 1986.

Trade in Services: Exports and Eoreign Revenues--Special

Report. Washington, D.C.: U.S. Government Printing office. Price Waterhouse. 1985. Exporting Services: A Fortune 500

View. Export Today $1: 53-57$.

Sampson, Gary P., and Richard H. Snape. 1985. Identifying the

Issues in Trade in Services. The World Economy 8:171-182.

Sapir, Andre. 1985. North-South Issues in Trade in Services.

The World Economy 8:27-42.

Schott, Jeffrey J. 1983. Protectionist Threat to Trade and

Investment in Services. The World Economy 6:195-214.

Stalson, Helena. 1985. U.S. Service Exports and Foreign

Barriers: An Agenda for Negotiations. Washington, D.C.:

National Planning Association.

Stern, Robert M. 1985. Global Dimensions of International Trade and Investment in Services. In Trade and Investment in

Services: Canada/US Perspectives, ed. Robert M. Stern.

Ontario Economic Council.

Stern, Robert M., and Bernard M. Hoekman. 1986. GATT Negotiations on Services: Analytical Issues and Data Needs. Research Seminar in International Economics, University of Michigan, Seminar Discussion Paper No. 189. 
United States International Trade Commission. 1982. The Relationship of Exports in Selected U.S. Service Industries to U.S. Merchandise Exports: USITC Publication 1290. Washington, D.C.: United States International Trade Commission, september.

United States Trade Representative. 1983. U.S. National Study on Trade in Services: A Submission by the United States Government to the General Agreement on Tariffs and Trade. Washington, D.C.: Office of the United States Trade Representative.

Urquhart, Michael. 1984. The Employment Shift to Services: Where Did It Come From? Monthly Labor Review 107 (April) $15-22$

Whalley, John. 1986. Some Reflections on the Current Trade in Services Debate. University of Western ontario. 
Tables for 2235

Table 6.1 U.S. Current Account by Major Component, 1977-85 (billions of dollars)

\begin{tabular}{|c|c|c|c|c|c|c|c|}
\hline & 1977 & 1980 & 1981 & 1982 & 1983 & 1984 & 1985 \\
\hline \multicolumn{8}{|l|}{ Merchandise tmade } \\
\hline Expolis & 120.8 & 224.3 & 237.1 & 211.2 & 201.7 & 219.9 & 214.0 \\
\hline Imports & 151.9 & 249.7 & 265.1 & 2476 & 268.9 & $33+.0$ & 338.3 \\
\hline Balance & 31.1 & -25.5 & -28.0 & -36.4 & -67.2 & $-1 \mid 4.1$ & --124.3 \\
\hline \multicolumn{8}{|l|}{ Business services } \\
\hline Exports & 23.4 & 37.0 & +1.7 & 41.7 & 41.8 & 43.8 & 45.1 \\
\hline Imports & 20.9 & 29.4 & 32.1 & 32.6 & 35.3 & 41.5 & 44.9 \\
\hline Balance & 2.5 & 7.6 & 9.6 & 9.1 & 6.4 & 2.3 & 0.2 \\
\hline \multicolumn{8}{|c|}{ International investment income } \\
\hline Exports (receipts) & 32.2 & 72.5 & 86.4 & 84.8 & 78.0 & 87.6 & 90.5 \\
\hline Imports (payments) & 14.2 & 42.1 & 52.3 & 55.3 & 52.6 & 68.5 & 65.8 \\
\hline Balance & 18.0 & 30.4 & 34.1 & 29.5 & 25.4 & 19.1 & 24.7 \\
\hline \multicolumn{8}{|l|}{ Other goods and services } \\
\hline Exports & 7.9 & 8.7 & 10.5 & 12.4 & 13.0 & 10.7 & 10.2 \\
\hline Imports & 7.2 & 12.2 & 13.1 & 14.5 & 14.7 & 14.0 & 13.6 \\
\hline Balance & 0.7 & -3.6 & -2.5 & -2.0 & -1.7 & -3.3 & -3.4 \\
\hline \multicolumn{8}{|l|}{ Total goods and services } \\
\hline Exports & 184.3 & 342.5 & 375.8 & 350.1 & 334.5 & 362.0 & 359.7 \\
\hline Imports & 194.2 & 333.5 & 362.6 & 350.0 & 371.5 & 458.0 & 462.6 \\
\hline Balance & -9.9 & 8.9 & 13.2 & 0.1 & -37.0 & -95.9 & -102.9 \\
\hline Net unilateral transfers & -4.6 & -7.1 & -6.8 & -8.1 & -8.9 & -11.4 & -14.8 \\
\hline Current account balance & -14.5 & 1.9 & 6.3 & -8.1 & -46.0 & -107.4 & -117.7 \\
\hline
\end{tabular}

Source: U.S. Department of Commerce 1986, table 40.
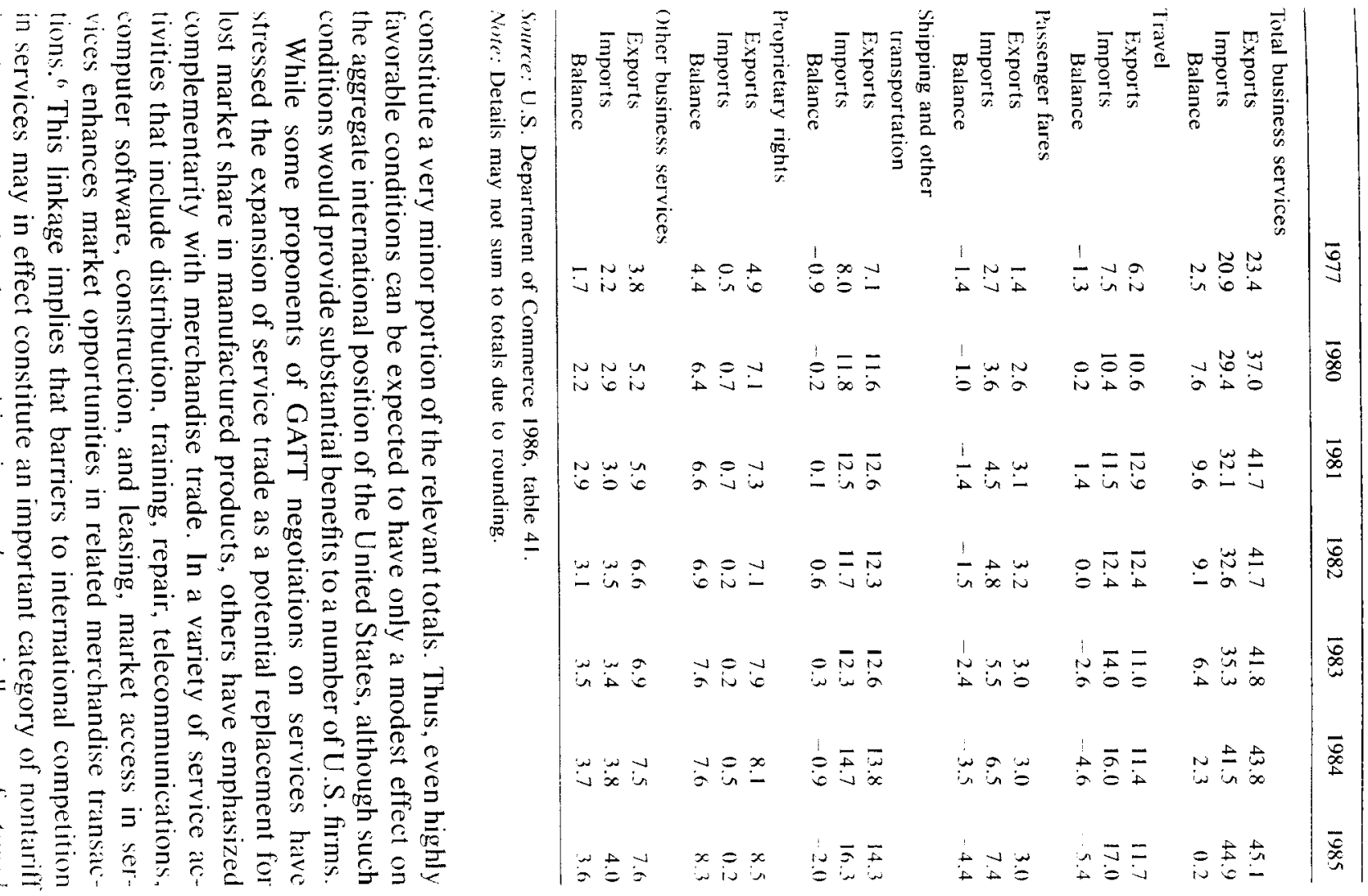
Table 6.3

U.S. Employment on Nonagricultural Payrolls by Industry. 1984-86 (thousands)

\begin{tabular}{|c|c|c|c|}
\hline Industry & 1984 & 1985 & 1986 \\
\hline Total & 94.496 & 97.614 & 99,918 \\
\hline Private sector & 78.472 & 81.199 & 83,198 \\
\hline Goods producing & 24.727 & 24.930 & 24,965 \\
\hline Mining & 966 & 930 & 790 \\
\hline Construction & 4.383 & 4.687 & 4.974 \\
\hline Manufacturing & 19.378 & 19.314 & 19.201 \\
\hline Service producing & 69,769 & 72.684 & 74.953 \\
\hline Transportation and public utilities & 5.159 & 5.242 & 5.265 \\
\hline Transportation & 2.917 & 3.006 & 3.037 \\
\hline Communications and public utilities & 2.242 & 2.236 & 2,228 \\
\hline Wholesale trade & 5.555 & 5,740 & 5,872 \\
\hline Retail trade & $16.5 \cdot 5$ & 17.360 & 17.464 \\
\hline General merchandise stores & 2.267 & 2,320 & 2.344 \\
\hline Food stores & 2.637 & 2.779 & 2.917 \\
\hline Auto dealers and service stations & 1.799 & 1,892 & 1.944 \\
\hline Eating and drinking places & 5.388 & 5.715 & 5.889 \\
\hline Financial. insurance. and real estate & 5.689 & 5.953 & 6,261 \\
\hline Finance & 2,854 & 2.979 & 3,137 \\
\hline Insurance & 1.757 & 1.830 & 1,918 \\
\hline Real estate & 1.078 & 1.144 & 1.206 \\
\hline Services & 20.797 & 21.974 & 22.924 \\
\hline Business services & 4.057 & 4.452 & 4.755 \\
\hline Health services & 6,122 & 6.310 & 6,543 \\
\hline Government & 16.024 & 16,415 & 16.720 \\
\hline Federal & 2,807 & 2.875 & 2.889 \\
\hline State & 3.734 & 3.848 & 3.936 \\
\hline Local & 9.482 & 9.692 & 9.885 \\
\hline
\end{tabular}

Source: Monthly Labor Review, October 1986, table 13.

Note: Data for 1984 and 1985 are annual averages: 1986 data are for May,

sectors are distinguished here by the intangible nature of their output and include both final-demand and intermediate-input categories.

As table 6.3 shows, U.S. employment is now heavily concentrated in the industries broadly described as service producing: transportation, public utilities, wholesale and retail trade, finance, insurance, real estate, miscellaneous business services. health, and government. This broad range of activities comprises all industries that are not included in the goods-producing sector, that is, manufacturing, construction. mining, and agriculture. The employment classification in table 6.3 is made on the basis of the industry's main output, which may be sold to final consumers (haalth, education), used as an intermediate input (business services). or both (restaurants) 


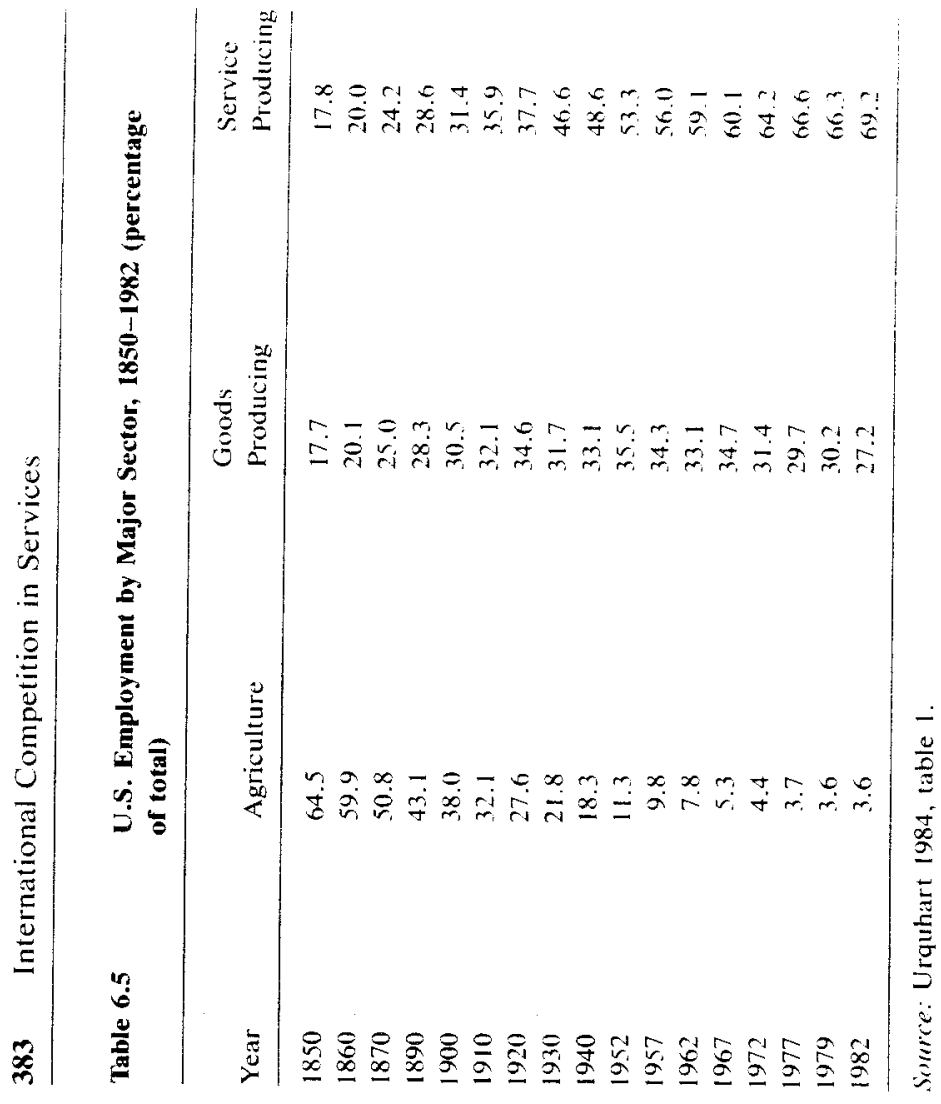

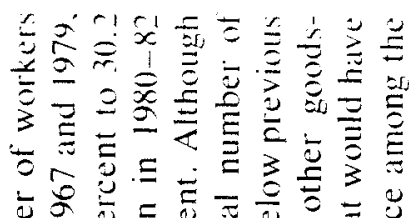

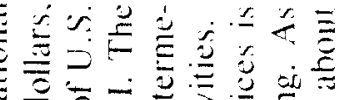

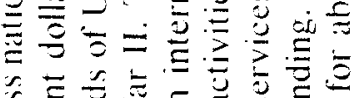



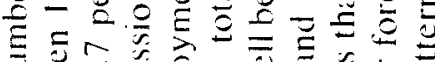

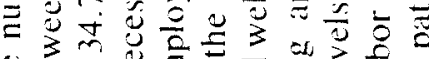

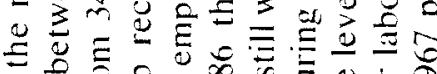

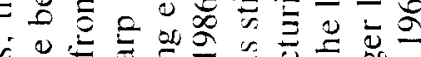

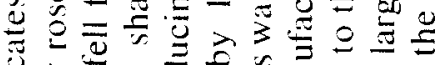

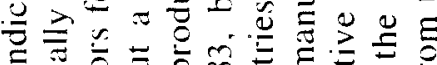

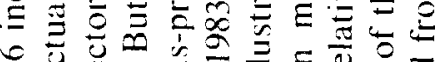
过

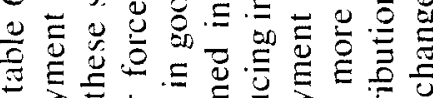

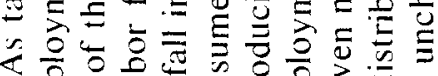

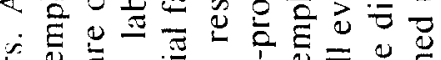

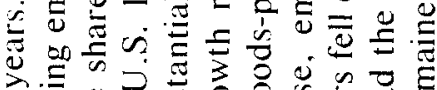

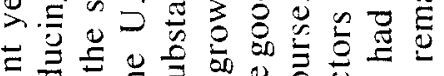

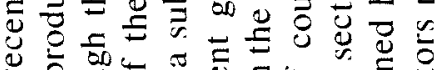



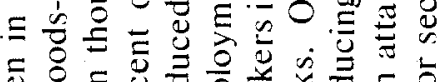

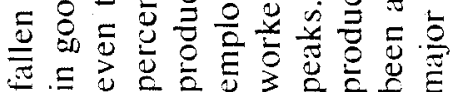

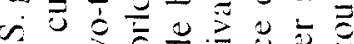

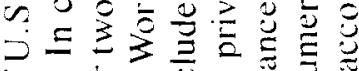

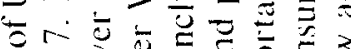

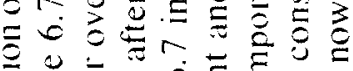

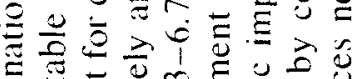

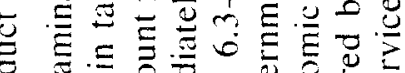

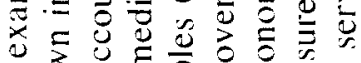



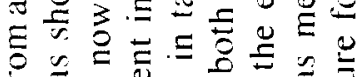

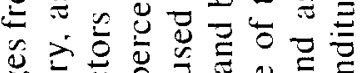

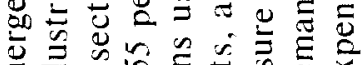

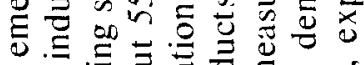

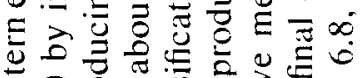
五

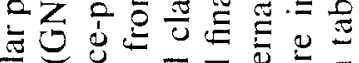

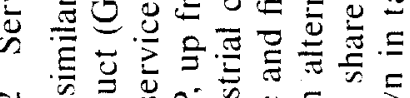
莳

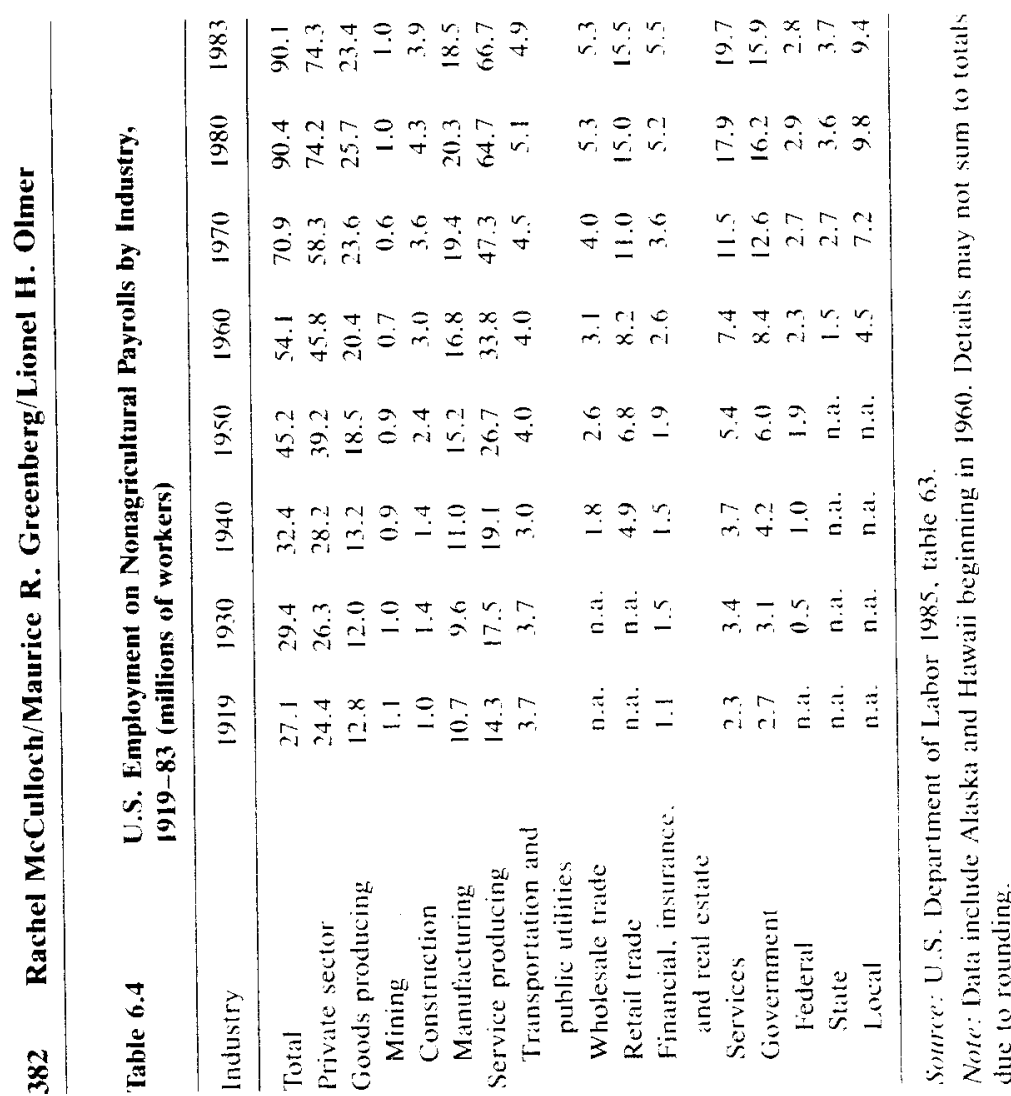

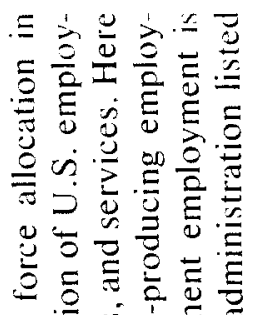

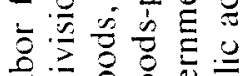

포용요

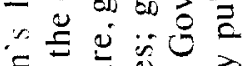

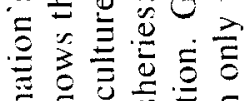

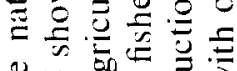

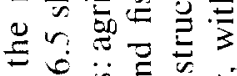

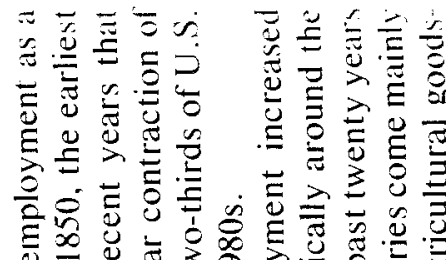



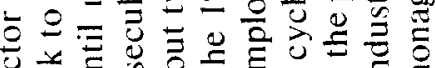



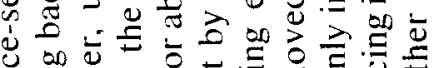

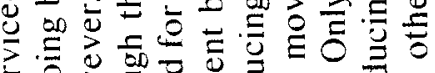



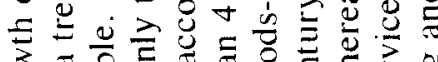
巳

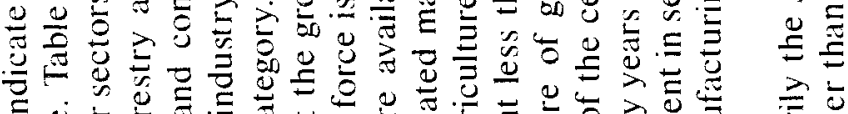

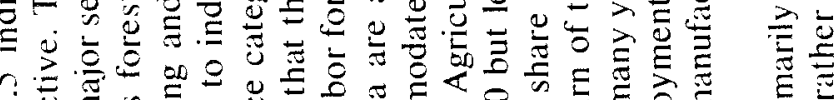



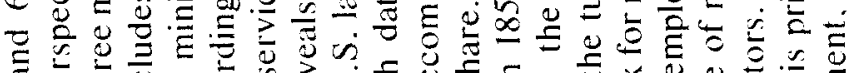

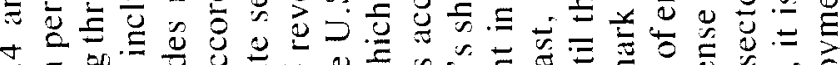


๘



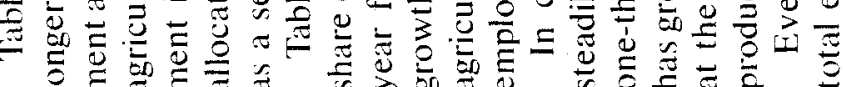


Rुutpunos ol onp

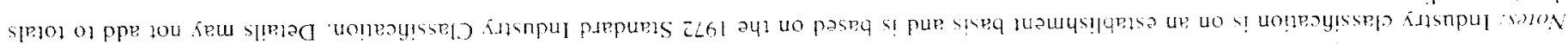

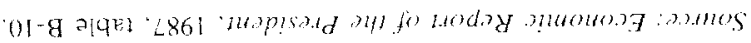

\begin{tabular}{|c|c|c|c|c|c|c|c|c|}
\hline$\tau \cdot 1 t$ & $9^{\prime} L t$ & $5 \angle 1$ & $\xi L$ & 85 & $\Xi \varepsilon$ & $5 \cdot 1$ & 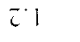 & pl.10n 241 10 15ad \\
\hline$s 5-$ & $6 \cdot t$ & $s i$ & I' I - & 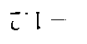 & $8 \cdot \tau-$ & 80 & 8.1 & 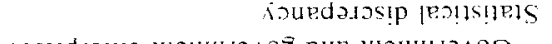 \\
\hline$\nabla L L t$ & 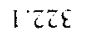 & 1012 & O'tEI & $\because 8 L$ & $z+5$ & $i+i$ & $\vec{c} 0$ & 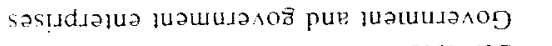 \\
\hline$t 6 \varepsilon 9$ & $0^{\circ} \nabla L \varepsilon$ & 8.661 & $\because 0 \pi$ & $9 \cdot t$ & $t \cdot 15$ & $i+i$ & $\tau \cdot 0 \tau$ & Sวग!A.JวS \\
\hline $9 \cdot 9 \overline{c 9}$ & $9^{\circ} 00 t$ & $L I Z$ & 8551 & $6 \cdot 86$ & $8 \cdot L$ & 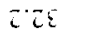 & $8 \cdot E \bar{c}$ & 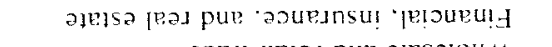 \\
\hline 5259 & $8 \cdot 8 \varepsilon t$ & $\angle E L Z$ & $\angle 89 !$ & $0 \subseteq 11$ & 258 & 515 & $\ddot{i} t$ & 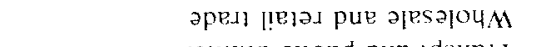 \\
\hline$\nabla \nabla L E$ & $8^{\circ} 0+2$ & 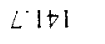 & +88 & $9 \cdot 29$ & $\varepsilon<t$ & $9 \cdot 9 \tau$ & 012 & so!!l!n s!lqnd pup d dsue.1 I \\
\hline$\varepsilon 0 L L \mathcal{Z}$ & $59 \angle \angle 1$ & $0^{\circ} \angle \succ 0 \mathrm{~L}$ & $1 \angle 59$ & $\varepsilon 6 \bar{t}$ & $F \| \varepsilon$ & $\angle 8 S I$ & $56 \overline{c l}$ & 3̈u!วnposd əolndes \\
\hline $8.56 L$ & 0.185 & $\varepsilon \angle S \mathcal{E}$ & $\varepsilon \bar{c}$ & 5.861 & $t-t t l$ & $0^{\circ}+8$ & $\overline{6} 99$ & 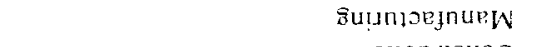 \\
\hline$\tau 281$ & $L \angle E I$ & 596 & $t 15$ & $L+\varepsilon$ & $\varepsilon \cdot t \bar{c}$ & $2 \varepsilon$ & $1 \%$ & uoliontisuog \\
\hline $8 \cdot \varpi \check{l}$ & $\varepsilon \angle 01$ & $\varepsilon ! t$ & 481 & $0+1$ & $8 \cdot \bar{c}$ & $\because 6$ & $8 \cdot 9$ & Bu!u!W \\
\hline$\$ 16$ & $\tau L L$ & $\varepsilon 95$ & $6 \cdot 6 \bar{c}$ & $\bar{c}+\bar{c}$ & Lì & 806 & $8.0 \bar{c}$ & 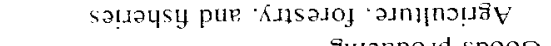 \\
\hline$\varepsilon 2611$ & $\tau \cdot \mathcal{\varepsilon} 06$ & t'ISS & $q \tau s \varepsilon$ & $\varepsilon I \angle C$ & $\tau \cdot \varepsilon 0 \tau$ & $\varepsilon \cdot し l$ & $6 \cdot 201$ & sutonposd spoos \\
\hline $1866 \varepsilon$ & $0 \tau \varepsilon L \bar{c}$ & +8651 & $s \zeta[0]$ & $150<$ & $\varepsilon S I S$ & $988 \pi$ & $\tau \varsigma \varepsilon z$ & $d N D[P] O \perp$ \\
\hline$\$ 861$ & 0861 & $S \angle 61$ & $0<61$ & $\$ 961$ & $096 \mathrm{I}$ & $0 \leq 61$ & $2+61$ & \\
\hline
\end{tabular}

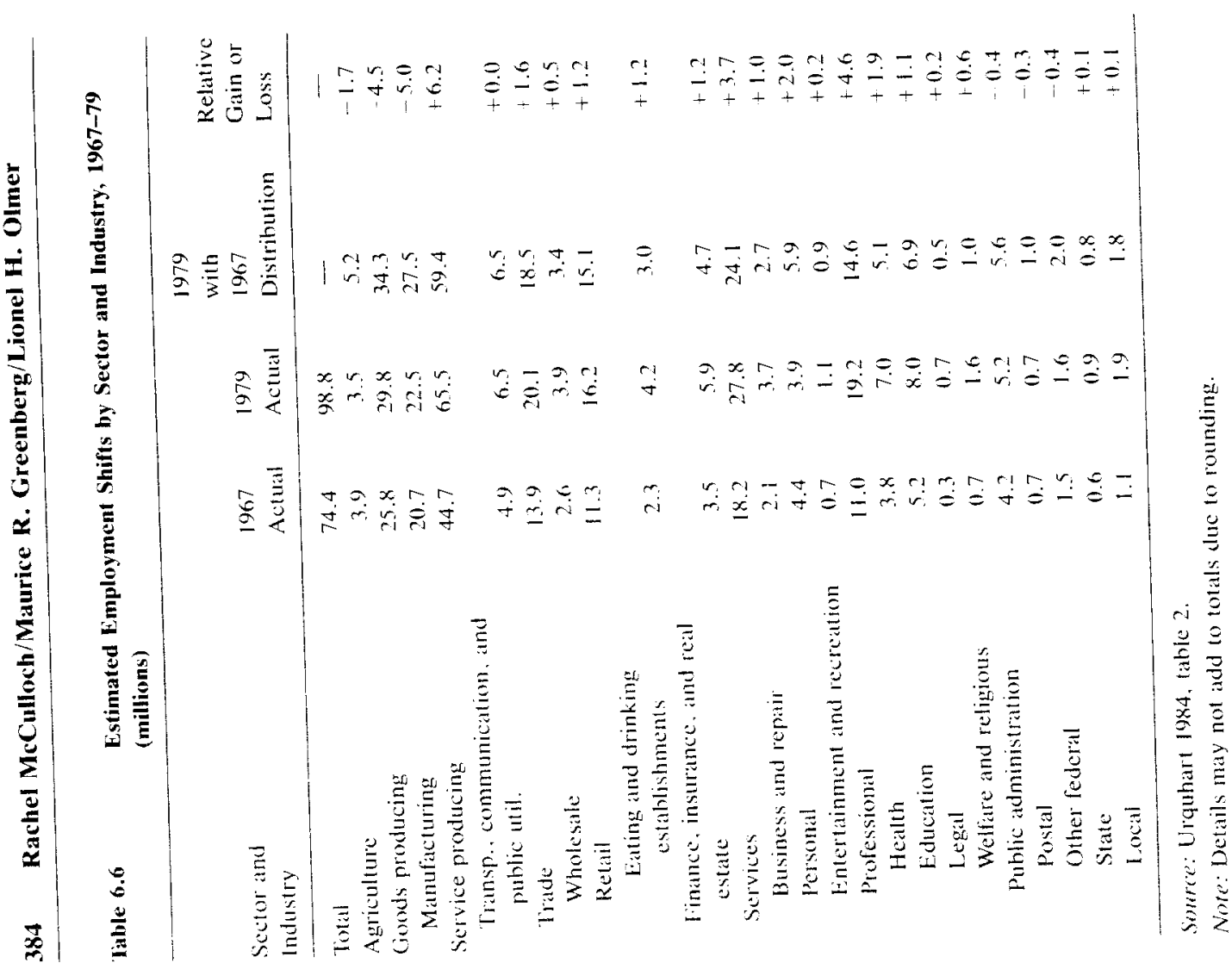






\begin{tabular}{|c|c|c|c|c|c|c|c|c|}
\hline \multirow[t]{2}{*}{ Table 6.8} & \multicolumn{3}{|c|}{$\begin{array}{l}\text { U.S. Personal Consumptio } \\
\text { of dollars) }\end{array}$} & \multicolumn{4}{|c|}{ Expenditures. 1929-86 (billions } & \multirow[b]{2}{*}{1986} \\
\hline & 1929 & 1940 & 1950 & 1960 & 1970 & 1975 & 1980 & \\
\hline Total & 77.3 & 71.0 & 192.1 & 330.7 & 640.0 & 1012.8 & 1732.6 & 2762.4 \\
\hline Durable goods & 9.2 & 7.8 & 30.8 & 43.5 & 85.7 & 135.4 & 219.3 & 388.7 \\
\hline Nondurable goods & 37.7 & 37.0 & 98.2 & 153.2 & 270.3 & 416.2 & 681.4 & 932.7 \\
\hline Services & 30.4 & 26.2 & 63.2 & 134.0 & 284.0 & 461.2 & 831.9 & 1441.3 \\
\hline Housing & 11.7 & 9.7 & 21.7 & 48.2 & 94.0 & 148.4 & 261.5 & 438.5 \\
\hline Household operation & 4.0 & 4.0 & 9.5 & 20.3 & 37.7 & 63.5 & 113.9 & 178.4 \\
\hline Transportation & 2.6 & 2.1 & 6.2 & 11.2 & 23.7 & 35.7 & 64.5 & 95.9 \\
\hline Medical care & 2.2 & 2.2 & 6.9 & 16.4 & 46.1 & 84.2 & 164.2 & 315.9 \\
\hline Other & 9.9 & 8.2 & 18.8 & 38.0 & 82.5 & 129.3 & 227.9 & 412.6 \\
\hline
\end{tabular}

Source: Economic Report of the President. 1987. table B-14.

Notes: Housing includes imputed value of owner-occupied housing. Data for 1986 are preliminary.

\subsubsection{Why and How Services Grew}

The summary tables presented in the previous sections document the evolution of today's "service economy" but give little insight into the causes of these dramatic changes. In brief, the employment and output shifts reflect the combined impact of three basic forces: changes in the sectoral allocation of final demand (in turn reflecting rising per capita income and systematic changes in relative prices as well as demographic shifts), relative rates of productivity improvement, and changes in the organization of economic activity.

Looking first at the long-term shift of employment out of agriculture offers some perspective on the more recent movements from goodsproducing to service-producing employment. In the case of agriculture. low income and price elasticities of demand, changing dietary preferences, and sustained high rates of productivity improvement have all contributed to agriculture's declining share of total employment, even over the periods when the United States was increasing its penetration of foreign markets.

Changes in the organization of economic activity reinforced the effects of demand and productivity changes, with specialized processing. transportation, distribution, and business-services units gradually taking over many functions once handled by workers classified as agricultural employees. But the nation is by no means losing its "agricultural base" in terms of production. On the contrary, agricultural outputs have continued to grow with dismaying rapidity despite the steady decline in the number of workers employed in the sector.

While the shift from goods-producing to service-producing employment is more complex, some of the same forces were important. Changes in the age composition of the population and in the labor force partic- 
These shares are calculated on the basis of local domestic prices. However, prices of services tend to be higher relative to those of tangible goods in countries with higher per capita GNP. When a common set of international prices is used to value outputs, the percentage shares of services in GDP differ less markedly over time for a given country or between rich and poor nations in a given year. Using realquantity indexes in place of value shares, Kravis, Heston, and Summers (1983) show that in real terms, low-income countries may actually consume services in higher proportions than wealthier nations. This finding presumably reflects the very low relative prices of services in poor countries.

\subsection{International Service Transactions}

The high priority placed by the United States on negotiations on trade in services is frequently justified by assertions that this trade is currently or potentially very important to the nation's overall international position. Yet the data on U.S. trade in services provide only weak support for such a claim. Globally and also for the United States, the aggregate size of services trade as reflected in balance of payments data is roughly one-fourth that of merchandise trade. Moreover, that

Table 6.9

Distribution of Labor Force by Industry, 1965 and 1980 (percentage of total labor force)

\begin{tabular}{|c|c|c|c|c|c|c|}
\hline \multirow[b]{2}{*}{ Country Group } & \multicolumn{2}{|c|}{ Agriculture } & \multicolumn{2}{|c|}{ Industry } & \multicolumn{2}{|c|}{ Services } \\
\hline & 1965 & 1980 & 1965 & 1980 & 1965 & 1980 \\
\hline Low-income economies & 77 & 73 & 9 & 13 & 14 & 15 \\
\hline Middle-income economies & 57 & 44 & 17 & 22 & 26 & 34 \\
\hline Oil exporters & 61 & 49 & 14 & 19 & 24 & 32 \\
\hline Oil importers & 53 & 40 & 19 & 23 & 28 & 36 \\
\hline High-income oil exporters & 56 & 36 & 15 & 21 & 28 & 44 \\
\hline \multicolumn{7}{|l|}{ Industrialized market } \\
\hline economies & 14 & 7 & 38 & 35 & 48 & 58 \\
\hline Canada & 10 & 5 & 33 & 29 & 57 & 65 \\
\hline France & 17 & 9 & 39 & 35 & 43 & 56 \\
\hline Germany & 10 & 6 & 48 & 44 & 42 & 50 \\
\hline Italy & 24 & 12 & 42 & 41 & 34 & 48 \\
\hline Japan & 26 & 11 & 32 & 34 & 42 & 55 \\
\hline United Kingdom & 3 & 3 & 47 & 38 & 50 & 59 \\
\hline United States & 5 & 4 & 35 & 31 & 60 & 66 \\
\hline $\begin{array}{l}\text { Eastern European nonmark } \\
\text { economies }\end{array}$ & 35 & 21 & 34 & 40 & 31 & 39 \\
\hline
\end{tabular}

Source: World Development Report, 1986. table 30.

Votes: Country groups are as defined by the World Bank. Group averages are weighted by population. 


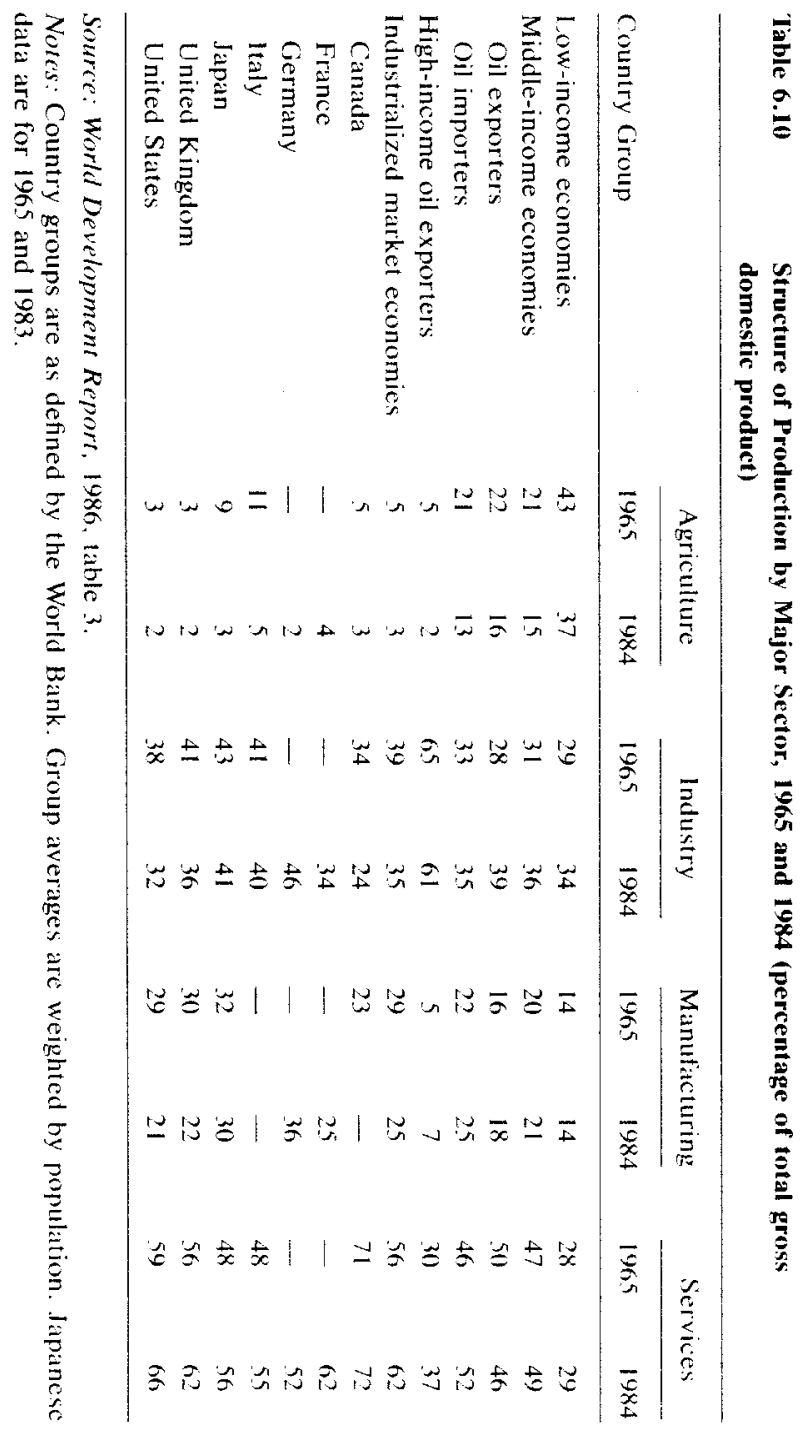




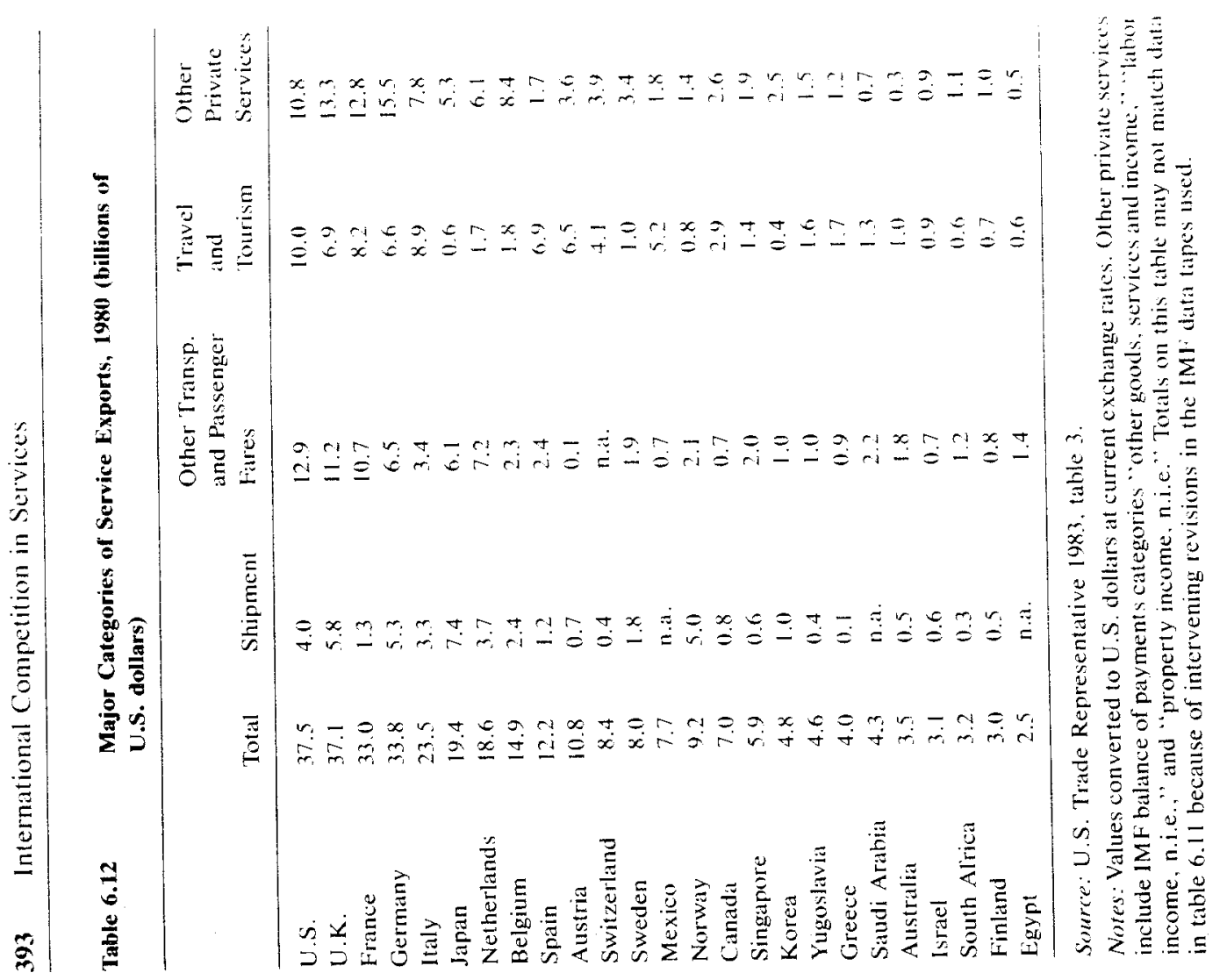

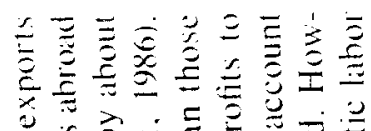
ن

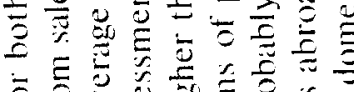

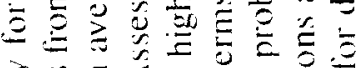

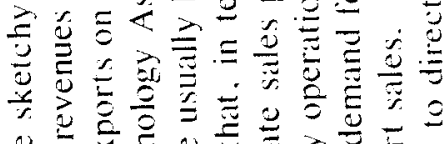

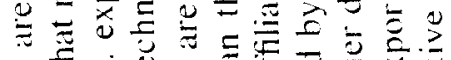

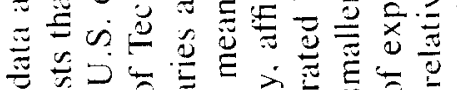

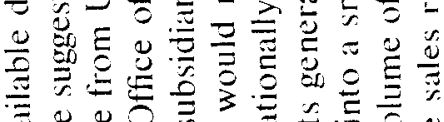

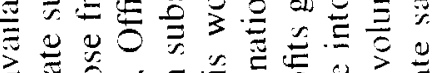

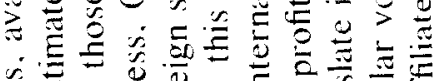

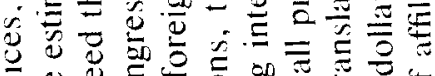

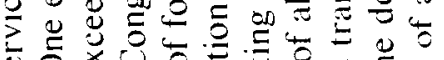

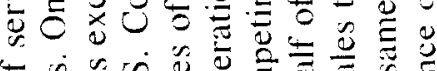

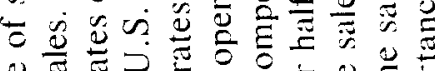

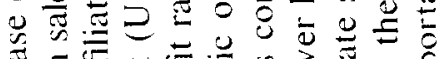



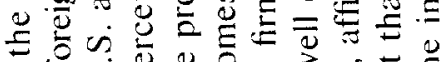

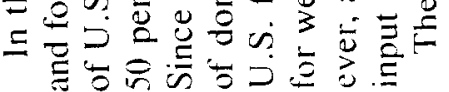
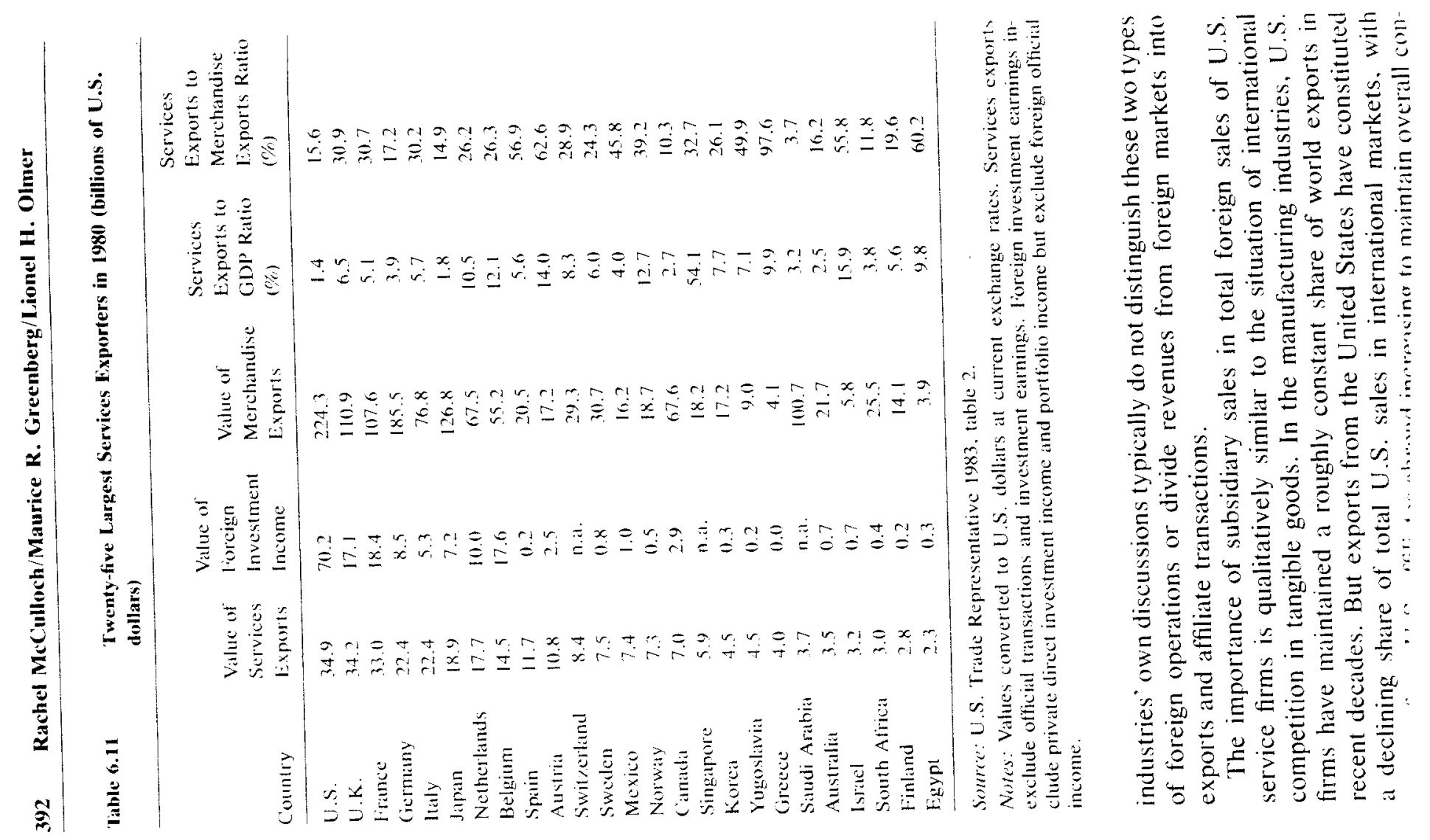
actions. For some major service industries, including travel, educational and legal services, and technology licensing, direct exports account for nearly all revenues from international transactions. In a second group, including insurance, advertising, and accounting, affiliate sales provide the bulk of foreign revenues. For a third group, including transportation, construction, consulting, and computer software, both direct exports and affiliate sales are significant. Table 6.13 shows Office of Technology Assessment estimates of 1983 revenues in both categories for U.S. service firms. Banking, an important service industry both domestically and in international transactions, was treated separately because of the special problem of distinguishing investment income from the service component of foreign revenues.

Given that affiliate sales greatly exceed exports for many service providers, a broader measure of the importance of international transactions to U.S. service industries is the size of total foreign revenues

Table 6.13

OTA Estimates of Foreign Revenues of U.S. Service Firms, 1983 (billions of dollars)

\begin{tabular}{lccc}
\hline & & & \\
Activity & $\begin{array}{l}\text { Direct } \\
\text { Exports }\end{array}$ & $\begin{array}{c}\text { Affiliate } \\
\text { Sales }\end{array}$ & $\begin{array}{l}\text { Total } \\
\text { Foreign } \\
\text { Revenues }\end{array}$ \\
\hline Accounting & $0.2-0.5$ & $3.7-4.0$ & $3.9-4.5$ \\
Advertising & $0.1-0.5$ & 1.7 & $1.8-2.2$ \\
Construction & 4.8 & $2.9-3.3$ & $7.7-8.1$ \\
Data processing & $0.1-1.2$ & $2.5-3.7$ & $2.6-4.9$ \\
Education & $1.6-2.3$ & $0.0-0.1$ & $1.6-2.4$ \\
Engineering & $1.1-1.6$ & 4.0 & $5.1-5.6$ \\
Franchising & $0.2-1.1$ & 0.0 & $0.2-1.1$ \\
Health & $1.0-2.5$ & 1.1 & $2.1-3.6$ \\
Information & $0.0-2.9$ & $0.0-2.9$ & 2.9 \\
Insurance & $2.7-3.6$ & $10.1-12.1$ & $12.8-15.7$ \\
Investment banking/brokerage & $1.0-2.0$ & 7.7 & $8.9-9.7$ \\
Leasing & $0.2-1.2$ & $3.7-5.4$ & $4.5-5.6$ \\
Legal & $0.0-2.0$ & 0.1 & $0.1-2.1$ \\
Licensing & 5.2 & 0.0 & 5.2 \\
Management/consulting & $0.6-1.4$ & 1.2 & $1.8-2.6$ \\
Motion pictures & 1.9 & 2.0 & 3.9 \\
Retailing & 0.0 & 25.4 & 25.4 \\
Software & $2.5-2.6$ & $3.2-4.4$ & $5.7-7.0$ \\
Telecommunications & 1.3 & 1.3 & 2.6 \\
Transportation & 17.1 & 10.9 & 28.0 \\
Travel & 14.1 & 0.0 & 14.1 \\
Miscellaneous & 5.3 & 6.0 & 11.3 \\
Subtotal (excluding banking) & $61.0-75.1$ & $87.5-97.3$ & $152-169$ \\
Banking & $n . \mathrm{a}$. & $n . \mathrm{a}$. & 9.4 \\
Total & $\mathrm{n} . \mathrm{a}$. & $\mathrm{n} . \mathrm{a}$. & $161-178$ \\
\hline SOurce: & & -1.9 &
\end{tabular}

Source: U.S. Congress. Office of Technology Assessment 1986, table 5. 